\title{
Towards quantitative environmental reconstructions from ancient non-analogue microfossil assemblages: Ecological preferences of Paleocene - Eocene dinoflagellates
}

\author{
Joost Frieling*, Appy Sluijs \\ Marine Palynology and Paleoceanography, Laboratory of Palaeobotany and Palynology, Department of Earth Sciences, Faculty of Geosciences, Utrecht University, \\ Princetonlaan 8a, 3584CB, The Netherlands
}

\begin{abstract}
A B S T R A C T
We explore a novel approach towards quantification of paleo-ecological signals from non-analogue microfossil assemblages by quantifying relations between assemblages and high-quality geochemical and sedimentological data from sedimentary archives. We test this approach using one group of microfossils, the organic cysts of dinoflagellates (dinocysts), which are widely used in shelf and open marine settings for biostratigraphy and reconstructions of past environments and environmental change. Similar to other microfossil groups, dinocysts can be used to reconstruct environments with relatively high confidence for recent time periods, as species affinities can be derived from observational and instrumental data. In the absence of such data, the ecology of extinct species is much less certain and as a result reconstructions in deep time are often limited to qualitative interpretations.

To explore if quantitative empirical relations between extinct dinocysts and high-quality geochemical data can be established, we study a major event of climate change, the Paleocene-Eocene Thermal Maximum (PETM; 56 Ma ago). The PETM is a particularly suitable period for this exercise as there is a multitude of large environmental perturbations associated with the transient global warming, such as deoxygenation, sea level rise and an accelerated hydrological cycle. The synthesized published dataset exhibits better spatial and temporal coverage compared to any other period in deep time. We extract empirical relations for the abundance of previously proposed paleoecological groups as a function of independent environmental proxies for example, sea surface temperature and terrestrial organic matter input.

The results unequivocally illustrate that many dinocysts show relations to several of the reconstructed environmental variables. Notably, we show that one genus (Apectodinium) and an ecogroup (epicystal Goniodomidae) required sea surface temperatures in excess of $20^{\circ} \mathrm{C}$, and $25^{\circ} \mathrm{C}$, respectively, while one species (Florentinia reichartii) was only abundant between 30 and $35^{\circ} \mathrm{C}$. Other groups apparently favored either a limited (Spiniferites) or high (Senegalinium) terrestrial input to the study site, relating to salinity, nutrient levels or suspended sediment load (i.e. murkiness).

Crucially, our work shows that the validation and quantification of ecological signals by independent environmental proxy data provides the opportunity to extract more quantitative information from a wide range of (non-analogue) microfossil assemblages. While this approach is not limited to any specific group of microfossils (or macrofossils), we stress that proper calibration datasets, high-quality sedimentological and geochemical proxy records, are needed and should ideally have decent geographical coverage and include one or more environmental perturbations. Using this approach such empirical relations can be established for a wide range of microfossil groups that have highly complementary geological records, which increases the value of existing data and ensures future application of microfossil-based paleoecology.
\end{abstract}

\section{Introduction}

Over the past decades, micropaleontology has evolved from taxonomic observations to tools used for biostratigraphy, and most recently reconstructions of the physicochemical environment (e.g. Van Der Zwaan et al., 1999; Sluijs et al., 2005; Raffi et al., 2009; Gradstein et al., 2012). Taxonomy and biostratigraphic application are continuously being refined, as can be seen in successive iterations of the international geological time scale (e.g., GTS2007-2012). However, micropaleontology-based environmental reconstructions are increasingly replaced by geochemical proxies and physical modeling, particularly because they provide quantitative estimates of past climatological or ecological parameters. While Holocene to Pliocene micropaleontology based reconstructions are becoming more quantitative based on transfer-functions, modern analogue techniques and coupled geochemical proxy data, increasing proportions of non-analogue systems and species prohibit such applications further back in time. However, as the preservation of original geochemical signatures in (biological) signal carriers deteriorates with time, the quality of geochemical proxy records becomes an increasingly limiting factor in further back in the geological record.

\footnotetext{
* Corresponding author.

E-mail address: j.frieling1@uu.nl (J. Frieling).
} 
The microfossil record is large and highly diverse. For the Phanerozoic, it includes planktic and benthic foraminifera, diatoms, radiolaria, silicoflagellates, ebridians, calcareous nannofossils (including coccolithophores), pollen and spores, and acritarchs. Paleoenvironmental reconstructions are carried out using all of these groups. However, these reconstructions are often carried out as standalone projects, focusing on a single group of microfossils and without supportive information from other (geochemical) proxies. Crucially, uncertainties in such reconstructions increase massively if it involves taxa that are extinct and have no living relatives. To alleviate some of these issues, some authors have attempted to derive species affinities using associative taxa, but this evidently carries risk of error propagation. Therefore new approaches to extract more quantitative information from non-analogue micropaleontological assemblage data are needed.

\subsection{Dinoflagellate cyst paleoecological potential}

Dinoflagellates are an ecologically diverse unicellular eukaryote plankton group (Fensome et al., 1996). They inhabit essentially all aquatic environments from fresh water to hypersaline lagoons, from oligotrophic gyres to upwelling zones, and some thrive in tropical waters whereas others have colonized sea ice systems (Zonneveld et al., 2013). Many free-living dinoflagellates have complex and often poorly understood life cycles, and some species may form a cyst in specific parts of their life cycle. The calcareous cysts are characteristic of about 30 species in the modern ocean (Fensome et al., 1993). However, a much larger fraction (13-16\%) of free-living (i.e. planktonic) dinoflagellate species produce preservable organic hypnozygotic (resting) cysts, or dinocysts, as an obligatory part of their sexual reproduction cycle (Evitt, 1985; Fensome et al., 1996). In addition, temporary (month scale) organic encystment may also occur in some dinoflagellates, typically induced by stress; the few morphological features of temporary cysts distinguishes them from the resting cysts (e.g. PeñaManjarrez et al., 2005). The hypnozygotic cysts have species-dependent characteristic morphologies, are often highly resistant to oxic and acid degradation and have excellent preservation potential (e.g. Fensome et al., 1996). Organic microfossils that can be confidently identified as dinocysts have been preserved in deposits as old as the early Triassic (MacRae et al., 1996), and recent phylogenetic evidence suggests their origin is likely not much earlier (Janouškovec et al., 2017).

The very rich fossil record and the high turnover rates make the group an excellent biostratigraphic tool, particularly in marginal marine settings and polar environments (e.g. Gradstein et al., 2012; Bijl et al., 2013a; Eldrett et al., 2014). In recent years, significant progress was made in revealing the molecular composition of the cysts (Versteegh et al., 2007; Bogus et al., 2012, 2014) and efforts to analyze their stable carbon isotope composition are emerging (Sluijs et al., 2007a, 2018; van Roij et al., 2016), which may ultimately lead to development of a new $p \mathrm{CO}_{2}$ proxy (e.g. Hoins et al., 2015).

Most importantly, dinocysts are widely used as paleoenvironmental indicators on all time scales (De Vernal et al., 2005; Matthiessen et al., 2005; Sluijs et al., 2005; Donders et al., 2009). Because of the high diversity of ecological preferences within dinoflagellates, dinocyst paleoecology is regarded as a valuable and widely applicable method, especially suitable for marginal marine deposits, in which carbonate microfossils are often scarce or poorly preserved.

\subsection{Implications of dinocyst classification}

For extant dinoflagellates many cell-cyst relations are now known (Head, 1996; Zonneveld et al., 2013), but for extinct species, this relation is impossible to resolve. Therefore, distinct nomenclature is in use for both the motile and resting cyst stages (Evitt, 1985). Paleontological dinocyst taxonomy is based on morphological characteristics of the cyst, which tracks to some extent the morphological characteristics in its motile dinoflagellate. Cyst-forming dinoflagellate cell membranes typically consist of a number of thecal plates $(20-30)$, secreted within vesicles. The thecal plates may be reflected in the dinocyst (e.g. Kokinos and Anderson, 1995). Although the relation between the theca and cyst is not straightforward, plate morphology and configuration, as well as ornamentation compose the backbone of the dinoflagellate and dinocyst taxonomies (Evitt, 1985).

Particularly with extinct taxa, it remains uncertain to what extent morphological variability truly reflects species diversity (MacRae et al., 1996; Finkel et al., 2007), or rather phenotypic plasticity or in some cases even preservation (e.g. Sluijs et al., 2005). Indeed, morphological variations in ornamentation often mark a morphological continuum between end-member species. Even within single strain cultures, changes in ornamentation related to environmental changes such as salinity and temperature (e.g. Ellegaard et al., 2002; Rochon et al., 2009) can be found and have been used to reconstruct environmental parameters (Mertens et al., 2009). Dinocyst paleoecology in the early Cenozoic has, hence, dominantly been applied on the level of dinocyst genera or groups of related genera (e.g. Schiøler et al., 1997; Sluijs and Brinkhuis, 2009; Harding et al., 2011).

\subsection{Transmission of dinoflagellate communities and ecological signals to sedimentary records}

In addition to taxonomic challenges, the dinocyst fossil record presents some important limitations. One of the limitations is that oceanic and coastal taxa may employ different encystment and excystment strategies; specifically, oceanic taxa are more likely to complete their life cycle in the water column compared to coastal taxa, which have a benthic stage (Dale, 1983; Dale and Dale, 1992; Matthiessen et al., 2005). As of yet, it is also not completely clear how dinoflagellate cysts reach the sediment. Most organic matter reaches the sediment water interface via flocculates (marine snow) or fecal pelleting of zooplankton, and although dinoflagellate cysts are not ubiquitous in marine snow or fecal pellets (Bursa, 1963; Reid and Boalch, 1987; Mudie, 1996; Alldredge et al., 1998) sediment trap data suggests fecal pelleting is the most likely transport mechanism (Zonneveld et al., 2010). Indeed, culture experiments have shown some calcareous cyst-building dinoflagellate species are capable of surviving ingestion by zooplankton (Montresor et al., 2003). Alternatively, empty cysts may be transported to the sediment as dinoflagellates complete their life cycle in the water column (e.g. Harland, 1983) although this trait is likely more common in oceanic species. In more distal regions, notably on the outer shelf, slope and continental rise, transport often plays a role in shaping the sedimentary plankton, dinocysts included (e.g. Dale and Dale, 1992). In addition, encystment in species is governed by a diverse set of factors including nutrient concentration, light and temperature (Anderson et al., 1984, 1985; Blanco, 1995; Nagai et al., 2004). Upon reaching the sediment, oxidation may bias the assemblage (Zonneveld et al., 1997b; Kodrans-Nsiah et al., 2008). It should also be emphasized that although many dinoflagellates show very strong seasonal responses to light, nutrients, temperature and salinity and interact with biota that show equally strong relations to these parameters, typically none of these seasonal signals or relations can be confidently extracted from the sedimentary record. Depending on local factors, bioturbation may erase up to multi-millennial scale variations.

Improving insights into the relationships between motile dinoflagellate cells in an ecosystem, the production of dinocysts and their incorporation in the sediment record increasingly allows to resolve smaller scale (i.e. species-level) interactions and affinities (e.g. Jephson et al., 2012; de Souza et al., 2014). For example, the proportion of cysts of heterotrophic dinoflagellates is likely related to the production of prey in the surface waters and thus nutrient supply (e.g. Naustvoll, 2000; Sherr and Sherr, 2007). Absolute numbers of cysts have therefore been used to track productivity in surface waters (Dale, 2009). 


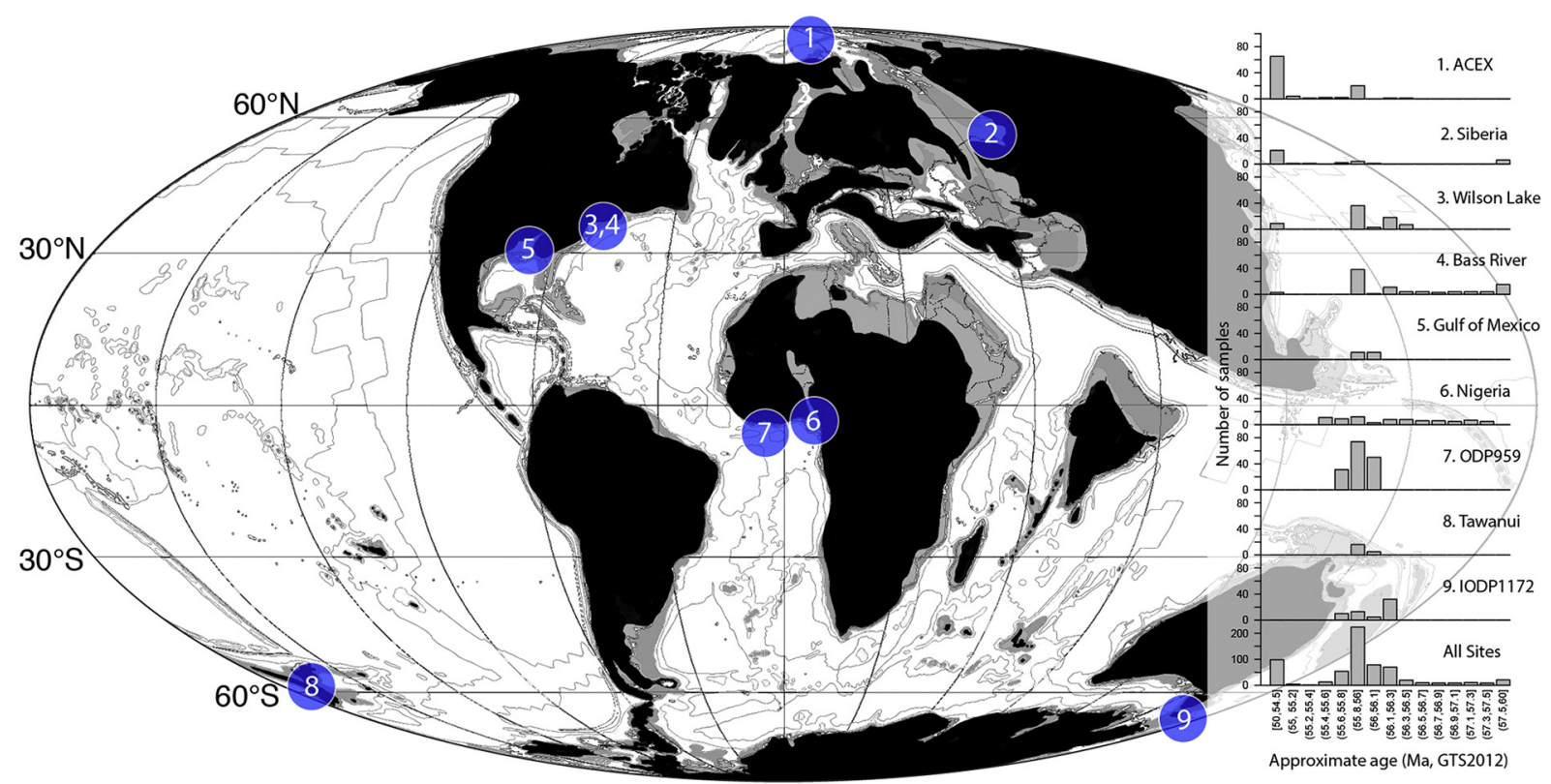

Fig. 1. Map of sites used in this study. 1. Arctic Coring Expedition (ACEX), Lomonosov Ridge 2. Well 10, West Siberian Sea, 3. Wilson Lake, New Jersey 4. Bass River, New Jersey 5. Harrell Core, Gulf of Mexico 6. IB10 cores and Sagamu Quarry, Nigeria 7. ODP Site 959, Cote d'Ivoire Ghana Transform Margin 8. Tawanui, New Zealand 9. ODP Site 1172, East Tasman Plateau. Note that the Sagamu Quarry site (only 7 samples) has been added to the IB10 cores (all Nigeria) for illustrative purposes.

Table 1

Sites and available data. References and proxy annotations: Reference: a (Sluijs et al., 2006), b (Sluijs et al., 2008a), c (Sluijs et al., 2009), d (Harding et al., 2011), e (Sluijs and Brinkhuis, 2009), f (Zachos et al., 2006), g (Eldrett et al., 2014), h (Frieling et al., 2014), i (Sluijs et al., 2014), j (Crouch et al., 2003), k (Crouch and Brinkhuis, 2005), 1 (Sluijs et al., 2011), m (Röhl et al., 2004), n (Frieling et al., 2018b), o (Frieling et al., 2017).

\begin{tabular}{lllllll}
\hline Site & Refs & Paleolatitude $\left({ }^{\circ} \mathrm{N}\right)$ & Species or genera $(\mathrm{n})$ & Samples $(\mathrm{n})$ & Proxy data & Remarks \\
\hline ACEX & $\mathrm{a}, \mathrm{b}, \mathrm{c}$ & 76.5 & 135 & 110 & $1,2,3,4,5,6,7,8,9$ & Early Eocene very restricted basin \\
Spitsbergen & $\mathrm{d}$ & 67.5 & 14 & 34 & - & Determinations to genus level \\
Bass River & $\mathrm{e}, \mathrm{f}$ & 34.6 & 110 & 91 & $1,2,4,6,10,11,12$ & \\
Wilson Lake & $\mathrm{e}, \mathrm{f}$ & 34.8 & 131 & 73 & $1,2,3,4,5,6,10,12,13,14$ & \\
Woensdrecht & $\mathrm{b}$ & 40.4 & 106 & 46 & - & \\
22-10A4 & $\mathrm{g}$ & 46.4 & 96 & 95 & - & Contains early Eocene \\
Well 10 & $\mathrm{h}$ & 51.3 & 198 & 45 & $1,2,3,4,5,6,8,9,13,14,15$ & one Paleocene sample \\
GoM & $\mathrm{i}$ & 31.1 & 44 & 12 & $1,2,4,5,6,10,11$ & \\
Tawanui & $\mathrm{j}, \mathrm{k}$ & -47.4 & 76 & 98 & $1,6,10,13$ & \\
ODP1172 & $\mathrm{l} \mathrm{m}$ & -58 & 122 & 60 & $2,3,4,5,6,7,16$ & \\
ODP 959 & $\mathrm{n}$ & -9.5 & 79 & 155 & $1,2,3,4,5,6,7,8,9,10,11,13,14,16,17$ & \\
BH10, Nigeria & $\mathrm{o}$ & -7.3 & 105 & 78 & $1,2,3,4,5,6,11,13,14,17$ & Only late Paleocene \\
Sagamu Quarry, Nigeria & $\mathrm{o}$ & -7.3 & 29 & 7 & $1,2,3,4,5,6,11$ & \\
\hline
\end{tabular}

Proxy annotations: 1 : TOC(wt\%), 2: $\mathrm{TEX}_{86}{ }^{\mathrm{H}}$, 3: BIT, 4: \%Red Sea GDGTs, 5: GDGT-2/cren, 6: Fraction of terrestrial palynomorphs, 7: Fe (counts per second, cps), 8:Ti/Al (XRF), 9: Ba/Al (XRF) 10: carbonate (\%),11: Magnetic susceptibility, 12: Sand fraction > 63um, 13: Ti/Al (ICP-OES), 14: Ba/Al (ICP-OES), 15: Fe (\%), 16: Ca (cps), 17: Corg/Ptot.

Note that 3 sites (Spitsbergen, Woensdrecht \& 22-10A4) do not have independent proxy data available and are not used in our analyses.

However, heterotrophic cyst production likely also depends on complex interactions and competition with other (heterotrophic) plankton groups.

Despite these limitations, dinocyst assemblages have yielded valuable and unique insights into paleoenvironments. The strength of the relations between species and environment can be established by determining empirical relations with environmental parameters (De Vernal et al., 2005). Indeed, many species have distinct environmental affinities in the modern ocean (Zonneveld et al., 2013). Modern analog techniques based on core-top sediment assemblages and environmental parameters have been successfully applied to the recent past (De Vernal et al., 2005; Radi and de Vernal, 2008; Datema et al., 2017). For deep time, however, we have to rely on the relationship of dinocyst species, genera or families to independent environmental proxy data. In this contribution, we aim to deduce environmental preferences of Paleogene dinoflagellates and their cysts by using proxies for environmental parameters, although it is obvious that these proxies have uncertainties as well.

We compile data from published sites in the mid and high latitudes on both hemispheres and the equatorial Atlantic (Fig. 1, Table 1), spanning the late Paleocene, Paleocene-Eocene Thermal Maximum (PETM) and early Eocene. For many of the sites used here, independent environmental proxy data is available, which allows for direct comparison to environmental variables and dinocyst response.

\section{The Paleogene, Paleocene - Eocene Thermal Maximum and dinoflagellate cysts}

The early Paleogene greenhouse has climatological and environmental characteristics that may serve as analogues for future climate change and for these purposes has been extensively studied (e.g. Zachos et al., 2008). Most well known is the PETM( $\sim 56 \mathrm{Ma})$, a period of 
Table 2

Most abundant dinocyst genera and primary ecological grouping. These genera comprise on average $96.3 \%$ of the assemblage encountered in all samples and in $95 \%$ of the samples, these genera comprise between 87 and $100 \%$. Note that the protoperidinioid group also includes a few rare brown-pigmented (bp) specimens otherwise attributable to Senegalinium. Note that some "groups" include only one genus or even species and that variations and subdivisions are tested (see also §3.3.1).

\begin{tabular}{|c|c|}
\hline Primary ecological grouping & Genera \\
\hline \multirow[t]{9}{*}{ Senegalinium complex } & Senegalinium \\
\hline & Phthanoperidinium \\
\hline & Cerodinium \\
\hline & Deflandrea \\
\hline & Lentinia \\
\hline & Vozzhennikovia \\
\hline & Manumiella \\
\hline & Alterbidinium \\
\hline & Spinidinium \\
\hline \multirow[t]{5}{*}{ Protoperidinioids } & Lejeunecysta \\
\hline & Phelodinium \\
\hline & Paleocystodinium \\
\hline & (bp Senegalinium*) \\
\hline & Trithyrodinium \\
\hline \multirow[t]{5}{*}{ Apectodinium complex } & Apectodinium \\
\hline & Wetzeliella \\
\hline & Dracodinium \\
\hline & Rhombodinium \\
\hline & Wilsonidium \\
\hline \multirow[t]{4}{*}{ Epicystal Goniodomideae } & Eocladopyxis \\
\hline & Polysphaeridium \\
\hline & Homotryblium \\
\hline & Heteraulacacysta \\
\hline \multirow[t]{4}{*}{ Spiniferites complex } & Spiniferites \\
\hline & Achomosphaera \\
\hline & Spiniferella \\
\hline & Hafniasphaera \\
\hline \multirow[t]{3}{*}{ Areoligera complex } & Areoligera \\
\hline & Glaphyrocysta \\
\hline & Adnatosphaeridium \\
\hline \multicolumn{2}{|l|}{ Hystrichosphaeridium } \\
\hline \multirow[t]{9}{*}{ Cordosphaeridium complex } & Cordosphaeridium \\
\hline & Lanternosphaeridium \\
\hline & Carpatella \\
\hline & Thalassiphora \\
\hline & Muratodinium \\
\hline & Ifecysta \\
\hline & Kenleyia \\
\hline & Fibrocysta \\
\hline & Turbiosphaera \\
\hline \multicolumn{2}{|l|}{ Diphyes } \\
\hline \multicolumn{2}{|l|}{ Florentinia reichartii } \\
\hline \multirow[t]{6}{*}{ Other gonyaulacoid cysts (apical archaeopyle) } & Batiacasphaera \\
\hline & Elytrocysta \\
\hline & Membranosphaera \\
\hline & Kallosphaeridium \\
\hline & Alisocysta \\
\hline & Eisenackia \\
\hline \multirow{7}{*}{ Other gonyaulacoid cysts (precingular archaeopyle) } & Cerebrocysta \\
\hline & Pyxidinopsis \\
\hline & Cribroperidinium? \\
\hline & Microdinium \\
\hline & Tectatodinium \\
\hline & Leptodinium \\
\hline & Trichodinium \\
\hline Impagidinium & \\
\hline
\end{tabular}

geologically brief (170 kyr, Murphy et al., 2010) global warming of $\sim 5{ }^{\circ} \mathrm{C}$ (Dunkley Jones et al., 2013; Frieling et al., 2017), associated with massive input of ${ }^{13} \mathrm{C}$-depleted carbon (Dickens et al., 1995). The PETM is further characterized by ocean acidification (Zachos et al., 2005; Penman et al., 2014), coastal deoxygenation (Dickson et al., 2012; Sluijs et al., 2014), intensified oxygen minimum zones (Zhou et al., 2016), local photic zone euxinia (Sluijs et al., 2006, 2014; Frieling et al., 2014, 2017; Schoon et al., 2015) and an intensified hydrological cycle (Pagani et al., 2006; Schmitz and Pujalte, 2007; Kopp et al., 2009).

In recent years, significant progress has been made in dinoflagellate cyst assemblage studies and several high-resolution records across the globe have been generated across the PETM (Egger et al., 2003; Crouch and Brinkhuis, 2005; Sluijs et al., 2008b, 2011; Sluijs and Brinkhuis, 2009; Harding et al., 2011; Kender et al., 2012; Eldrett et al., 2014; Frieling et al., 2014, 2018b). These records typically rely on dinoflagellate cyst assemblage characteristics to reconstruct paleoenvironment and paleoceanography.

The number of dinocyst species found for the extended period of time from the late Paleocene through the early Eocene is often impractical for use in paleoenvironmental reconstructions, especially considering the high diversity that marks the early Paleogene (MacRae et al., 1996). Therefore it is common practice to evaluate data based on so-called ecogroups or select species to which specific affinities have been attributed (e.g. Brinkhuis, 1994; Pross and Brinkhuis, 2005; Sluijs et al., 2005; Torricelli et al., 2006). For example, the Senegalinium complex is considered to be tolerant of lower than marine salinity (e.g. Sluijs and Brinkhuis, 2009; Barke et al., 2012). The ecogroups (or complexes) are usually centered on one genus, and include genera and species with similar taxonomical affinities.

\section{Data and methodology}

\subsection{Available dinocyst assemblage and proxy data}

We use published data from 10 sections (Table 1, Fig. 1), each with independent stratigraphic control in the form of carbon isotope stratigraphy and/or calcareous microfossil biostratigraphy. In this paper, we distinguish the Paleocene, Eocene and PETM data, which is taken from the published literature. For each of the 10 sections we use here, there is dinocyst data available with determinations at least to the generic level and in most instances to the species level (number of samples $=624$ ). In order to use statistically sound measurements of dinocyst assemblages, typically only samples with at least 200 cysts determined to at least the genus level are included $(n=544)$, which can then be used for direct comparison between dinocyst assemblages and proxy records.

None of the proxies have been generated on all included sites (Table 1). In contrast, for some records, two or more independent proxies have been applied to reconstruct the same environmental parameter. We therefore discuss the variability of assemblages in relation to the environmental variable the proxy record represents, i.e., $\mathrm{TEX}_{86}$ is used as a proxy for sea surface temperature (SST). Although paired proxy-assemblage data from the exact same sample is ideally used, some proxy data has been interpolated to match the sample depth of the dinocyst assemblage data and maximize the potential of the datasets used here.

Furthermore, it is important to note that the tropical sections especially show a marked drop in diversity and dinocyst numbers during the PETM, which is likely caused by heat-stress (Frieling et al., 2017, 2018b). The counts for these samples are often low and hence would typically be excluded from quantitative analyses. In contrast with other dinocyst assemblage studies we choose to include these samples in our analyses as they reflect meaningful ecological information and do not simply represent bad data.

Dinocyst assemblage studies typically normalize the abundance of dinocysts relative to the total, resulting in relative abundances. The most important disadvantage of this method is the closed-sum effect, i.e. the relative increase in one species could in fact be due to a decrease in the absolute abundance of another species and vice versa. Ideally, assemblage studies based on relative abundances are thus supplemented by quantitative numbers or fluxes. We here use the relative abundance because it allows for straightforward comparisons between sites, with the note of caution that in some cases the closed-sum effect 
a

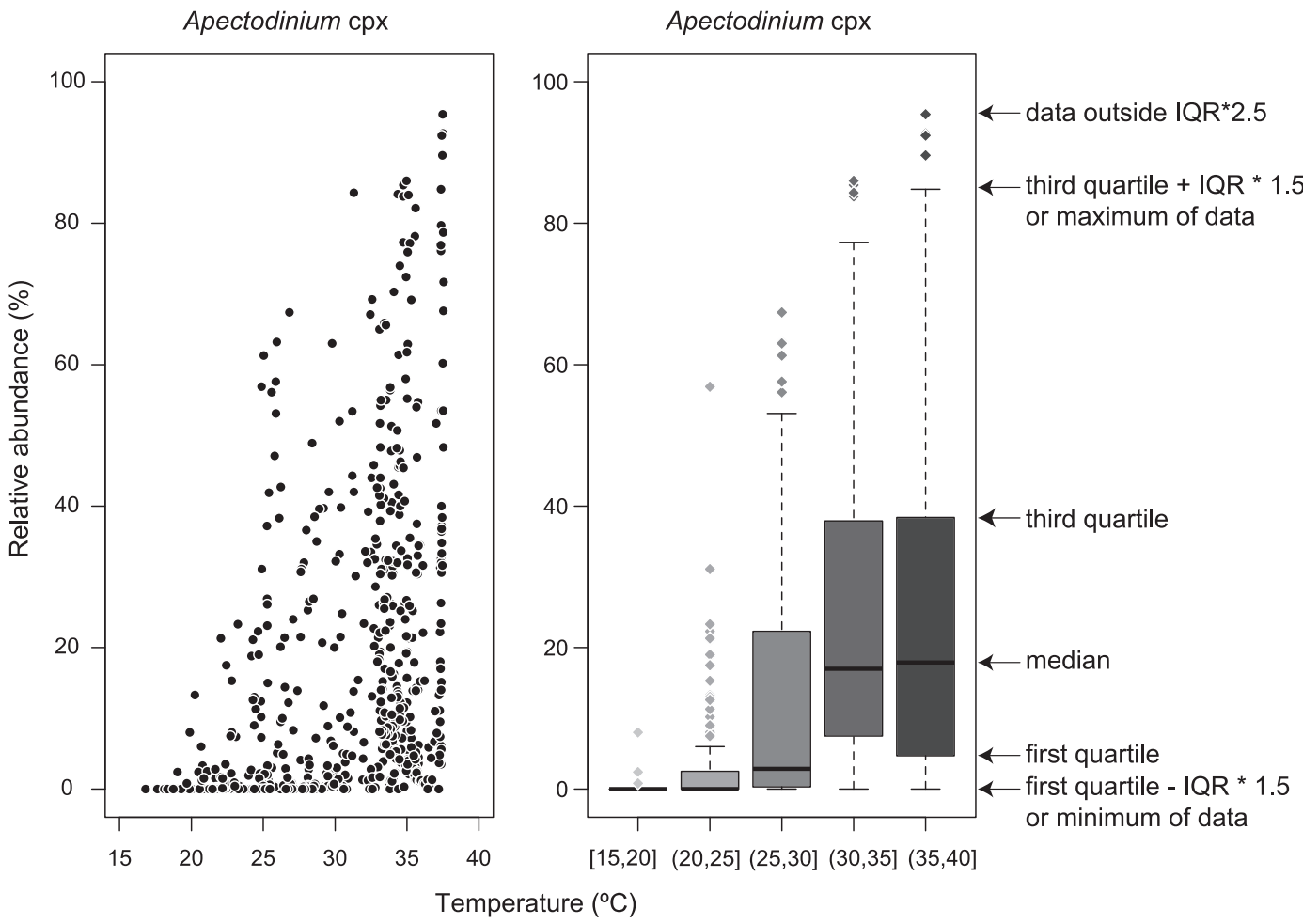

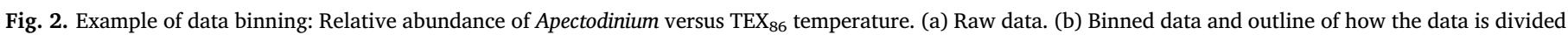
across the box and whisker plots.

may play a role in observed trends. However, absolute quantitative data (in cysts per gram of sediment) presented in the source studies (Table 1) typically mimic the trends recorded in the relative abundances (e.g. Sluijs and Brinkhuis, 2009) indicating that the closed-sum effect is a minor factor. Regardless, future work may focus on dinocyst accumulation rates, allowing for quantitative comparisons of several sites although this remains difficult at marginal marine sites with highly variable sediment accumulation rates.

\subsection{Independent environmental proxies}

For all study sites, independent geochemical and sedimentological environmental proxy data is available, generated in parallel with the dinoflagellate assemblages, typically although not exclusively, on the same samples. Each proxy is linked to one environmental parameter using biogeological experiments or core top calibrations from the modern ocean. Reconstructions based on these data are not always unambiguous because of potential diagenesis (e.g., dissolution, recrystallization, remobilization of trace elements under anoxic conditions), uncertainties regarding calibrations (for proxies with modern core top calibrations such as the glycerol dibiphytanyl glycerol tetraether (GDGT) based proxy $\mathrm{TEX}_{86}$ ), or the potential influence of environmental parameters other than the target parameter (e.g., salinity effect on foraminifer oxygen isotope paleothermometry). Therefore, it is important to note that we assume that the independent proxy data correctly reflect their target parameter. However, we present these data in bins reflecting a range of values, which is expected to minimize this uncertainty.

We use $\mathrm{TEX}_{86}$ for sea surface temperature reconstructions (Schouten et al., 2002). The branched and isoprenoid tetraether (BIT) index is used (Hopmans et al., 2004), in tandem with other proxies, such as terrestrial (pollen and spores) over marine (here dinocysts and organic linings of foraminifera) palynomorphs (e.g. Sluijs and Dickens, 2012), to reconstruct terrestrial input. Weight percent total organic carbon
(TOCwt\%) and organic carbon over total phosphorus ratio (Corg/Ptot; Ingall and Van Cappellen, 1990) provide insight into productivity and seawater oxygen concentrations. Building on modern ocean floor sediment distribution maps, weight percent carbonate (carb\%) and coarse fraction $(\%>63 \mathrm{um})$ are used as a proxy for shore proximity or sea level (e.g. Sluijs and Brinkhuis, 2009). We also explore the use of the potential stratification proxy based on isoprenoid GDGT ratios, specifically the relative abundance of the crenarchaeol regio-isomer (cf. Inglis et al., 2015).

\subsection{Methodology}

\subsubsection{Dinocyst grouping}

As a starting point for our analyses, we use the grouping of dinocysts as defined by Sluijs and Brinkhuis, (2009), who studied the PETM in two sections from the New Jersey Shelf. We apply some minor modifications and additions to better accommodate variability of all sections included here (see Table 2 for groups and selected genera). These include sections from polar to equatorial regions, and from coastal to open marine settings. This should, hence, include most of the important groups from this time interval, enabling a complete analysis on which environmental factors were dominant in determining the distribution of cyst-forming dinoflagellates.

The ecological grouping of Sluijs and Brinkhuis (2009) is itself largely derived from previous work (Brinkhuis, 1994; Schiøler et al., 1997; Pross and Brinkhuis, 2005; Sluijs et al., 2005). The most pronounced difference from the grouping of Sluijs and Brinkhuis (2009), is that the diversity in our data allows us to divide Peridinioid cysts with a hexagonal archaeopyle into 4 groups and test their individual responses: protoperidinioids (following Guasti et al. (2005) as Lejeunecysta-group), Cerodinium, Phthanoperidinium and Senegalinium. The remaining cyst genera, mostly gonyaulacoid cysts with low ornamentation are divided on morphological parameters; here we group them according to archaeopyle type (apical or precingular). Groups and genera are listed in Table 2. 


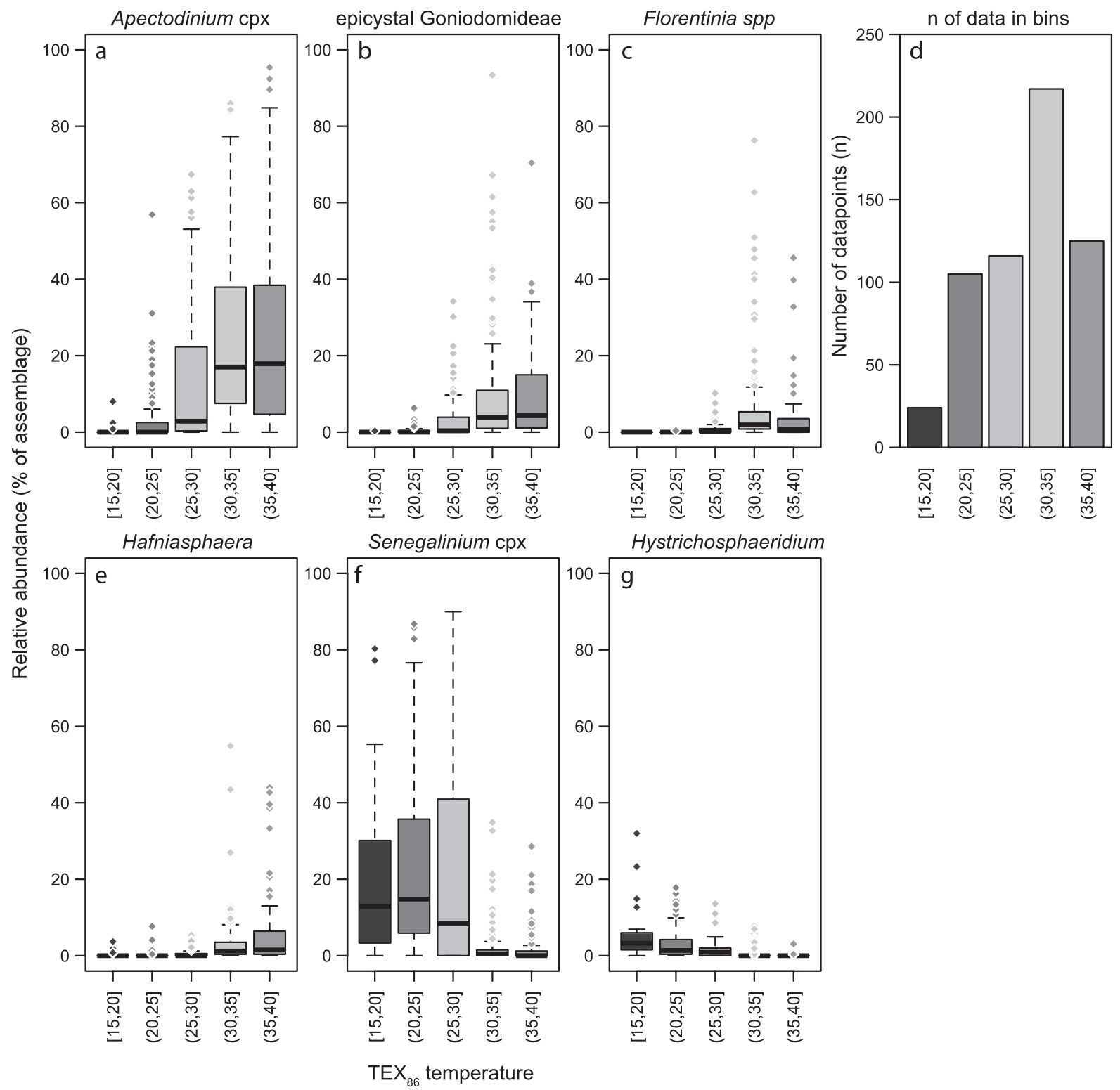

Fig. 3. Relation of relative abundance of selected ecological groups with $\mathrm{TEX}_{86}$ and number of data in $\mathrm{TEX}_{86}$ biIs ns.

\subsubsection{Proxy binning}

To optimally test for ecological preferences, we have divided the full range of proxy values into $5-10$ bins. This allows for better readability of illustrations as well as a simple definition of uncertainty in the recorded relations between abundance and environmental parameter (see Fig. 2a and b). The box-whisker plots represent the data as follows: the box represents $50 \%$ of all data in the bin, and the thick black line in the middle is the median. Upper and lower end of the box represent the interquartile ranges (IQR; 25 and 75 percentiles). The upper and lower whiskers are calculated from the IQR and represent a maximum (minimum) of 1.5 times the IQR from the median or the maximum (minimum) of the data (Fig. 2). Consequently, data points outside the whiskers represent data $>2.5$ IQR from the median. Cut-off values for bins are chosen with readability and comparison to existing and forthcoming data in mind. For example, the BIT index data is divided into 9 bins, with each bin spanning 0.1 BIT units and the percentage of terrestrial palynomorphs (\%TP) is divided into 8 bins where each bin spans $10 \%$. The distribution of data across the bins has virtually no influence on representation of the trends in the data. However, due to distribution of proxy data, the bins are typically not of equal sizes and we include the number of data in each bin in the plots. In addition, for some proxies, such as TOCwt $\%$ and coarse fraction, the high and low values are likely to have proportionally very different impacts. Logtransformation of the proxy data could partially counteract these effects, but we choose to separate the data into bins of unequal width as it allows for more straightforward comparison.

\section{Discussion and results}

\subsection{Temperature}

Temperature dependent distribution is well known for many biota and species of dinocysts have been successfully employed as relative temperature indicators in a number of sections both in recent and deep time sediments (e.g. Brinkhuis et al., 1998; Penaud et al., 2010; Datema et al., 2017). Indeed, a number of dinocyst groups in our data appear temperature limited (Fig. 3a, b, c). For example, Apectodinium does not occur in great abundance below $20^{\circ} \mathrm{C}$ (Fig. 3a; Frieling et al., 2014). Apectodinium expanded its geographical range polewards during the PETM (Bujak and Brinkhuis, 1998; Crouch et al., 2001; Sluijs et al., 


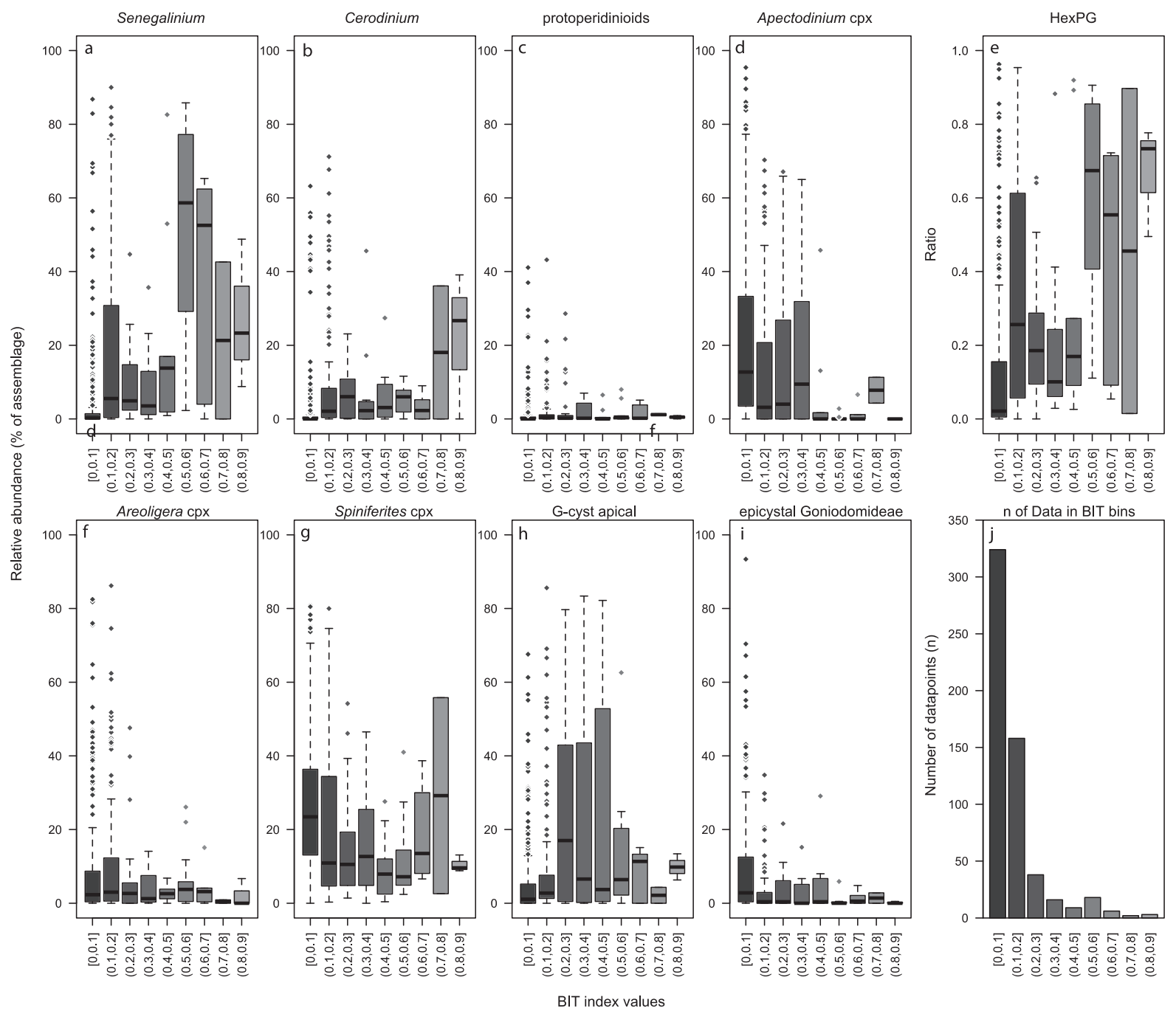

Fig. 4. Relation of relative abundance of selected ecological groups to BIT index and HexPG ratio and number of data points in each bin.

2007b) and Eocene Thermal Maximum 2 (ETM2) (Sluijs et al., 2009) and Apectodinium and its family Wetzelielloideae in general increase in abundance at higher latitudes during the Early Eocene Climate Optimum (EECO) (Bijl et al., 2013b; Frieling et al., 2014). The increased abundance of Apectodinium around the PETM in particular has been explained as a direct response to temperature (Bujak and Brinkhuis, 1998). For some locations and periods, this may indeed be the case (Frieling et al., 2014), but for most locations other environmental factors, such as coastal proximity, nutrients and fresh water input, are considered more important in controlling its presence and abundance (Sluijs et al., 2007b; Sluijs and Brinkhuis, 2009).

Compared to Apectodinium, epicystal Goniodomideae and Florentinia reichartii appear even less low-temperature resilient and have not been recorded below $25^{\circ} \mathrm{C}$ (Fig. 3b) and $30^{\circ} \mathrm{C}$ (Fig. 3c), respectively. The reduced meridional temperature gradients in the late Paleocene and early Eocene (Bijl et al., 2009; Inglis et al., 2015; Frieling et al., 2017; Cramwinckel et al., 2018) imply that relatively small temperature changes could lead to substantial latitudinal shifts in habitats. Our data suggest that the lower temperature bounds play a vital role in poleward species migrations during the PETM such as that of Apectodinium, as well as epicystal Goniodomideae and F.reichartii, which arguably have even higher optimal temperatures than Apectodinium. Notably, F.reichartii exhibits a narrow distribution of optimal temperatures, which may imply that it was more sensitive to small temperature changes and less well adapted to fluctuating or adverse environmental conditions. In this light, Apectodinium had a much wider optimal temperature range, suggesting high adaptability to such conditions, which partly explains its global expansion during the PETM.

Some genera within complexes also show specific relations to temperature, most notably seen in Hafniasphaera, a genus within the Spiniferites complex. Hafniasphaera had a high optimal temperature and does not occur in great abundance below $25^{\circ} \mathrm{C}$ (Fig. 3e). This is an important observation since we can now positively identify Hafniasphaera as a thermophilic genus, which is consistent with its poleward migration during the PETM (Fig. 11).

Limitations to high temperature also appear from our data set, although much less obvious than the low temperature bound. However, this is not necessarily surprising from a modern ocean perspective as taxa that tolerate high-latitude temperatures are often not intolerant to conditions at lower latitudes (Sunday et al., 2011). Although it is unclear whether the same is widely applicable to dinoflagellates (Zonneveld et al., 2013), higher temperatures for high latitude species typically prove less of a challenge than low temperatures for low latitude species (Tewksbury et al., 2008).

Senegalinium was more abundant at lower temperatures (Fig. 3f). However, this result is almost certainly influenced, in our dataset, by the unique combination of relatively low salinity and low temperature in the Arctic Ocean (Sluijs et al., 2008a) where salinity played a more crucial role (see Section 3.2). An affinity with lower temperatures is also observed in Hystrichosphaeridium (Fig. 3g), which unlike the trend 

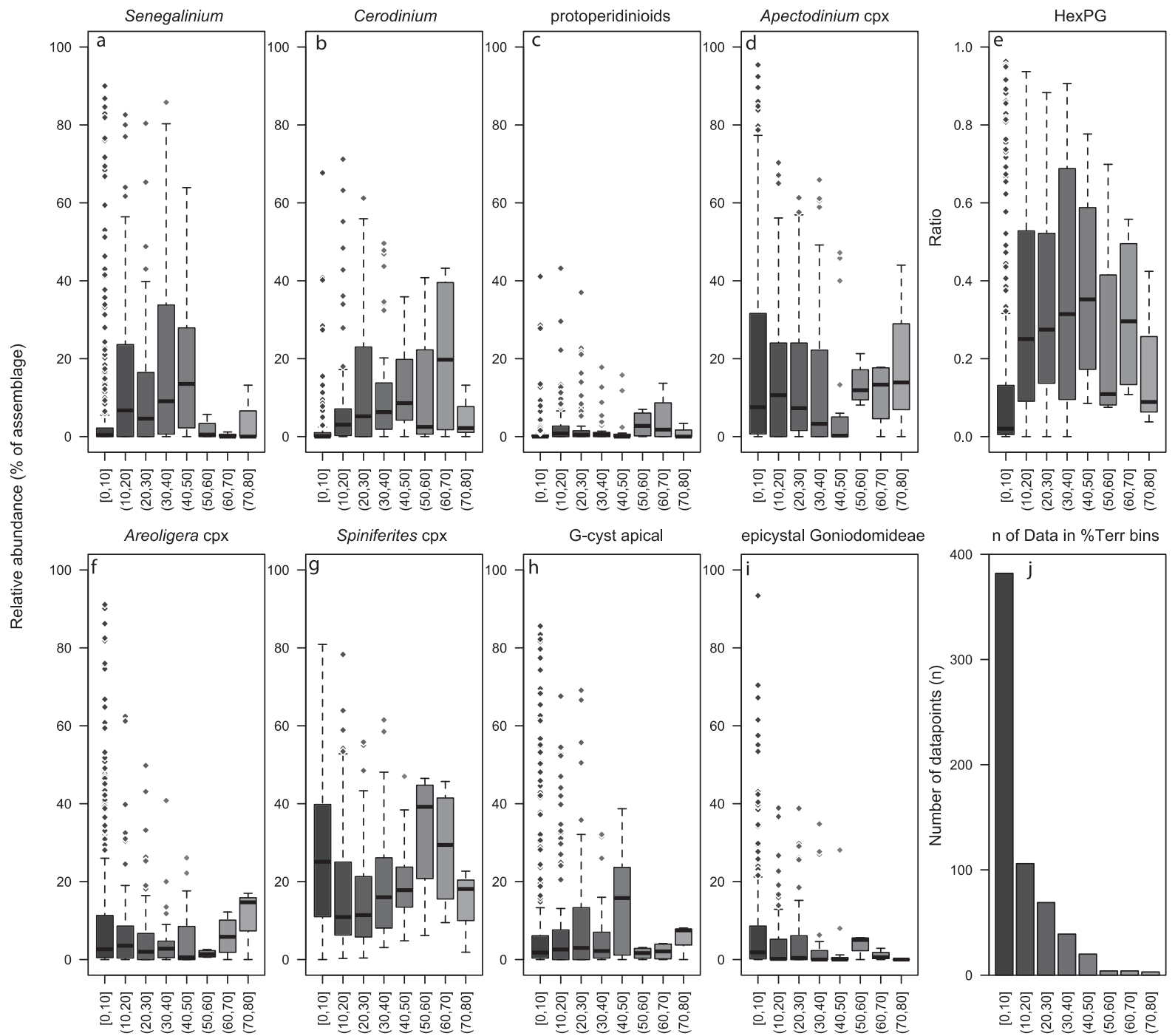

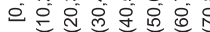

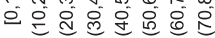

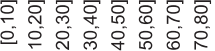
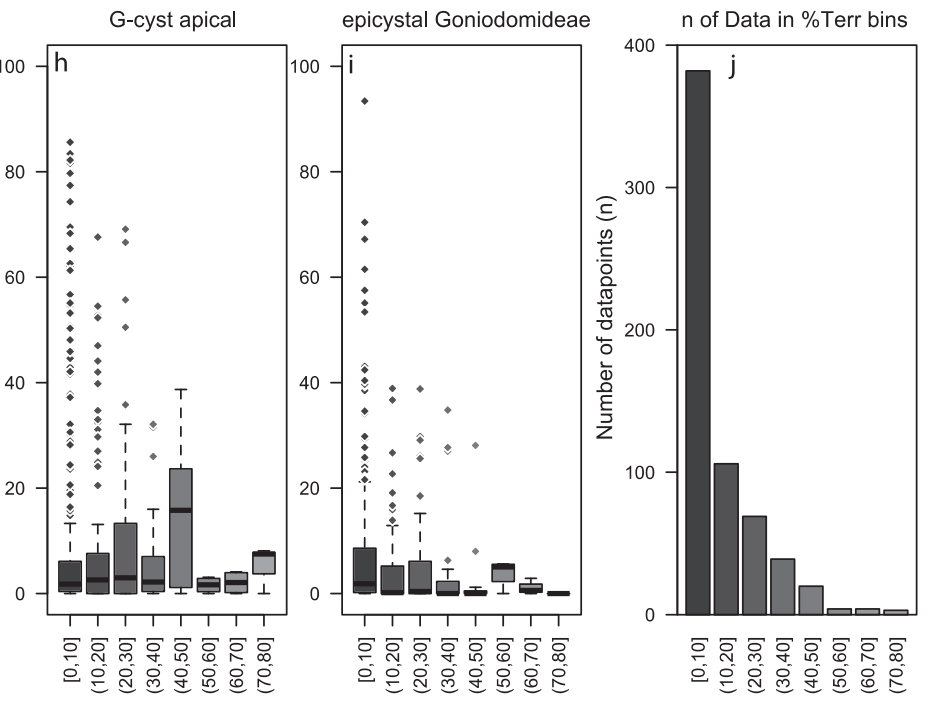

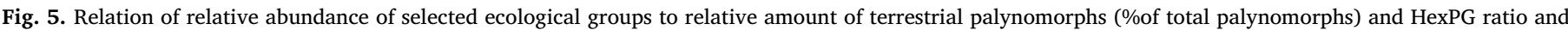
number of data points in each bin.

observed in Senegalinium, cannot be explained by lowered salinity, as it negatively correlates to the terrestrial organic matter input proxies BIT and \%TP (Figs. 4a, 5a).

\subsection{Salinity and terrestrial input}

Several groups show a relation with BIT (Fig. 4) and \%TP (Fig. 5). As expected, periods of high terrestrial input tend to favor species in the Senegalinium complex (sensu Sluijs and Brinkhuis, 2009), a group that was particularly abundant in the Arctic (Brinkhuis et al., 2006; Sluijs et al., 2008a; Barke et al., 2012). The opposite appears to be true for the Areoligera complex (cpx), which supports previous studies that report high abundance of this group associated with transgressive systems tracts (Powell et al., 1996; Schiøler et al., 1997; Iakovleva et al., 2001; Sluijs et al., 2008b). Also epicystal Goniodomideae show a weak anticorrelation with BIT and \%TP (Figs. 4i, 5i). This is intriguing since epicystal Goniodomideae have been associated with transgressive system tracts (e.g. Sluijs et al., 2008b) and warm stratified waters with high and fluctuating salinity (Zonneveld et al., 2013) in the modern and the Paleogene (Pross and Brinkhuis, 2005). Considering the weak anticorrelation with BIT and \%TP we surmise that high relative abundances of this group in Paleogene sediments are thus particularly associated with seasonally elevated salinity levels. In the modern, they are among the few dinoflagellates producing cysts under such hot near-shore conditions. In our dataset, high-salinity environments and transgressive system tracts are likely partially coupled because much data points are from the PETM interval. This implies that the importance of the individual factors is difficult to assess. Indeed, also at individual sites it appears that the abundance of epicystal Goniodomideae can be either salinity driven, through open-ocean stratification (ODP Site 959; Frieling et al., 2018b) and/or related to transgressive phases (Bass River \& Wilson Lake; Sluijs et al., 2008b).

Notably, gonyaulacoid cysts with an apical archaeopyle show highest abundances in samples with intermediate values for BIT and \%TP ratios (Figs. $4 \mathrm{~h}, 5 \mathrm{~h}$ ). This could indicate a certain degree of tolerance to lower than marine salinity in this group.

\subsection{Nutrient levels and productivity}

Sluijs et al. (2005) reviewed the application of the relative abundance of peridinioid (P) cysts relative to gonyaulacoid (G) cysts to reconstruct the availability of nutrients. This $P / G$ ratio is based on the observation that in the modern ocean, many $\mathrm{P}$ taxa are heterotrophic, particularly the brown-pigmented protoperidinioids, while G 

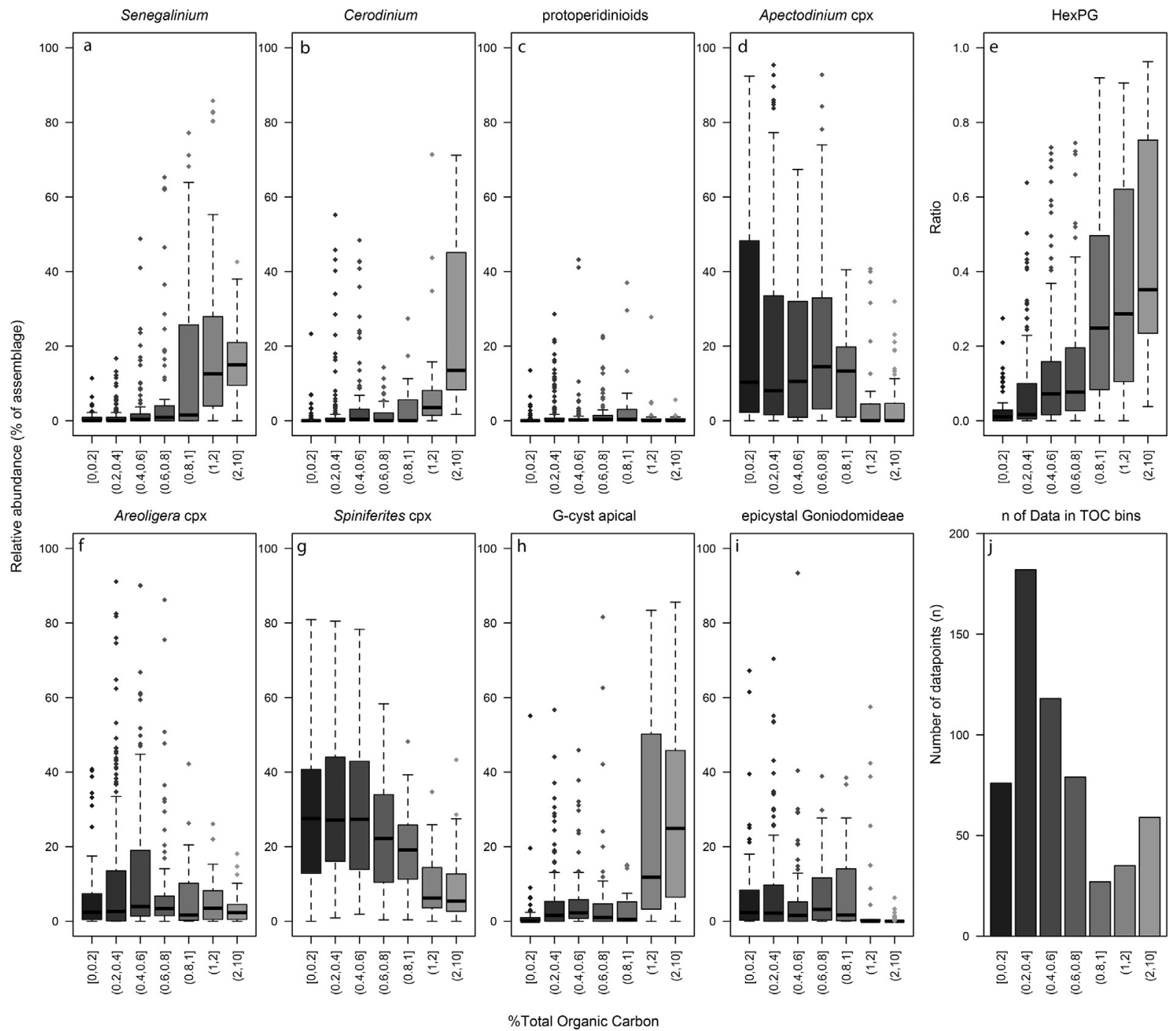

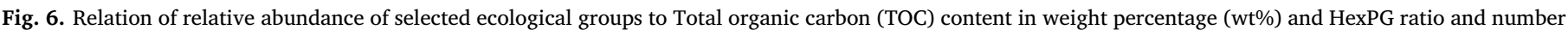
of data points in each bin.

dinoflagellates are mostly autotrophic. However, the ratio between $\mathrm{P}$ and G cysts, defined as the number of species rather than specimens (as used in most subsequent studies; see Sluijs et al., 2005 and discussion therein), was originally designed to assess salinity (Harland, 1973). Indeed, P-cysts Senegalinium, Phthanoperidinium, Deflandrea and Cerodinium are typically considered tolerant to low salinity (Brinkhuis et al., 2006; Sluijs et al., 2006; Sluijs and Brinkhuis, 2009; Barke et al., 2012). While these genera do not produce brown-pigmented cysts, they are commonly considered to have been heterotrophic, feeding on primary producers in coastal and upwelling environments (e.g. Brinkhuis, 1994; Firth, 1996; Sluijs et al., 2005), similar to many, although not all (Dale and Fjellså, 1994), of their modern (proto)peridinioid counterparts.

The Protoperidinioideae subfamily of obligate heterotrophic dinoflagellates produces typical brown-pigmented cysts, are an exclusively heterotrophic group in the modern ocean and often found in higher abundances in upwelling zones (e.g. Marret, 1994; Zonneveld et al., 2013). Remarkably, protoperidinioid dinocysts are usually not very abundant across the PETM, and in the entire early Paleogene, except locally (e.g. Cramwinckel et al., 2018). Long-term evolution and/or expansion of protoperidinioid-dominated systems such as found in Arctic and Antarctic regions was likely tightly coupled to the availability of niches (sea ice) and prey species (i.e. diatoms; Houben et al.,
2013) and the same is possibly true for upwelling zones (Cramwinckel et al., 2018).

We also find that some sections, particularly in the tropical Atlantic are characterized by higher relative abundances of protoperidinioid cysts during the PETM. Although relative percentages are high, the absolute abundances are low and hence this may represent a subsurface signal during extreme warming rather than an indication of elevated nutrient concentrations (Frieling et al., 2017, 2018b). Therefore, it can be that, in general, the ratio of heterotrophic over autotrophic cysts tracks total productivity (Dale, 1996), but not necessarily dinoflagellate productivity.

Using terrestrial input (\%TP and BIT) and TOC content as general indicators for the amount of nutrients and productivity, clear trends emerge that supports a heterotrophic (i.e. high productivity) and/or low-salinity tolerant affinity for the Senegalinium complex. Overall, these show increased abundance with higher terrestrial input (BIT and marine terrestrial ratio) and total organic carbon (Figs. 4-6).

Intriguingly, it appears that Apectodinium behaves differently from other peridinioid genera (Figs. 4-6). The abundance of Apectodinium has previously been used to argue that productivity was enhanced during the PETM (e.g. Bujak and Brinkhuis, 1998; Crouch et al., 2001; Sluijs et al., 2007b). However, the nutrient or trophic affinity of Apectodinium, the most abundant peridinioid genus in many PETM sections, 

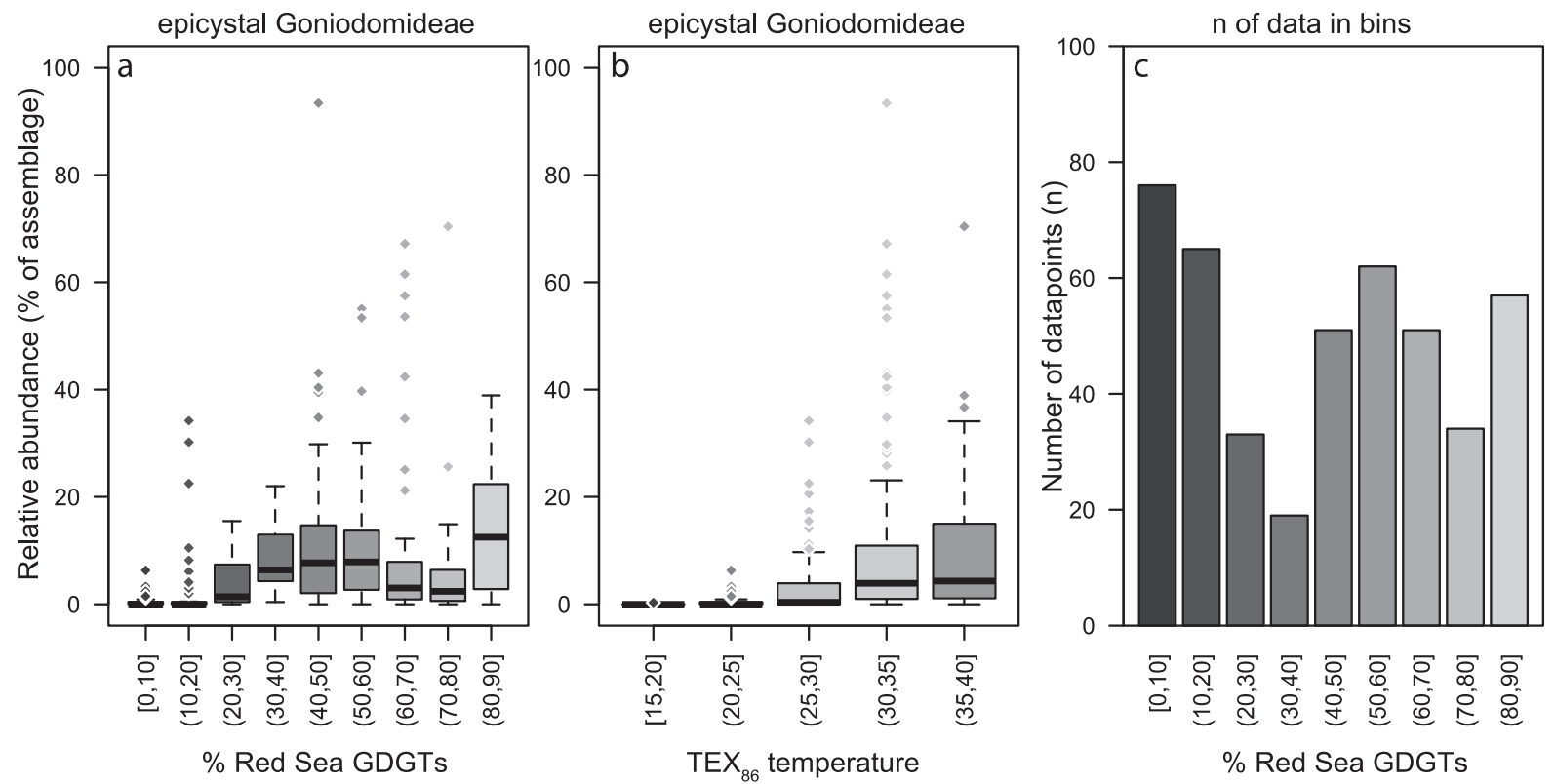

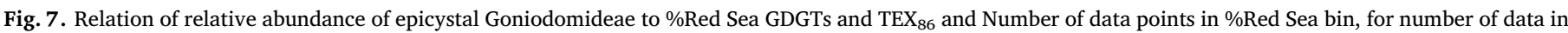
TEX $_{86}$ bin, see Fig. 3d.

is not well resolved. Apectodinium stands out morphologically relative to other peridinioid genera analyzed here by the rectangular rather than hexagonal shape of the intercalary 2a plate. Although Apectodinium may occur in great abundance during the PETM and occurs in some numbers in environments with significant terrestrial input, the general trend in our data suggests it does not particularly favor environments with very high terrestrial input or high organic carbon percentages (Figs. 4-6). This strongly contrasts with peridinioid cysts with a hexagonal 2a plate (e.g. Senegalinium, Cerodinium, protoperidinioids), summarized in the HexP/G ratio (Figs. 4-6). We therefore speculate Apectodinium may not be an obligate heterotroph, unlike many other peridinioid dinoflagellates. Circumstantial supporting evidence for this may come from stable carbon isotope data that show a relatively large magnitude PETM carbon isotope excursion relative to other species and carbonate proxy carriers, suggesting $\mathrm{CO}_{2}$-dependent fractionation (Sluijs et al., 2018). Moreover, mixotrophic capabilities would have provided the ecological flexibility to become globally successful during the PETM. We argue that, in the light of uncertainty involved in the trophic affinity of Apectodinium, using the HexP over gonyaulacoid cysts in addition to the traditional $\mathrm{P} / \mathrm{G}$ ratio provides a range estimate for the relative abundance of the heterotrophic group and hence nutrient availability.

\subsection{Stratification and turbulence}

Inglis et al. (2015) noted a remarkable co-occurrence of so-called "Red Sea"-type GDGT distributions (\%RS), which are thought to reflect a Thaumarcheotal community adapted to hyperhaline stratified waters (Trommer et al., 2009), and epicystal Goniodomideae at Ocean Drilling Project (ODP) Site 1172. Representatives of epicystal Goniodomideae are still abundant in the modern ocean and typically occupy warm stratified, hyperhaline, but also meso- and polyhaline waters (Zonneveld et al., 2013). Although it may be complicated to distinguish between "Red Sea"-type GDGT distributions and very high temperatures (Inglis et al., 2015 and §3.2), this potentially represents one of the first molecular tools for the identification of hyperhaline and/or stratified waters.

Although the match between epicystal Goniodomids and \%RS at Site 1172 is very intriguing, the translation to global dinoflagellate assemblages is more complex (Fig. 7a). In general the epicystal
Goniodomideae are indeed associated with higher \%RS, but both the fractional abundance of GDGT-0 and the crenarcheol regio-isomer are also strongly correlated to temperature (Schouten et al., 2002). Furthermore, high \%RS is not exclusively associated with epicystal Goniodomideae and absence of either one does not preclude the presence of the other. High temporal abundances of epicystal Goniodomideae are recorded at both ODP Site 959 and Dahomey Basin sites, but ODP Site 959 is characterized by continuous presence of high \%RS, whereas the Dahomey Basin sites record more normal marine distributions. In apparent contrast with the view of stratification-driven abundance of epicystal Goniodomideae, Sluijs et al. (2011) speculated that the high transient abundance of the epicystal Goniodomideae at ODP Site 1172 may be the result of increased storminess. This hypothesis is based on the notion that modern epicystal Goniodomideae blooms may relate to sediment resuspension during a storm (Villanoy et al., 1996, 2006; Siringan et al., 2008). The high abundance of epicystal Goniodomideae may hence result from abundant storms that are followed by strong stratification due to the large fresh water supply in their wake. Such conditions are fairly common in (sub)tropical regions and may become more common at higher latitudes at higher temperatures (McCabe et al., 2001; Villarini and Vecchi, 2013). Finally, recent single-species carbon isotope work has indicated that Paleocene-Eocene epicystal Goniodomideae also occurred in intense seasonal blooms, based on their very high carbon isotope ratios (Sluijs et al., 2018), which suggests an intense growing season under seasonally stratified warm conditions, perhaps following a storm event or season.

\subsection{Oxygen levels}

Anoxic zones in the modern ocean are expanding (Stramma et al., 2008; Schmidtko et al., 2017) and therefore economic and public interest in reconstructing anoxia in past environments has risen. Anderson et al. (1987) found that absence of oxygen often prevents excystment, but the extent of the effects of very low oxygen concentrations may vary between species (Keafer et al., 1992). In the modern oceans, planktic dinoflagellates seem to have clearly different tolerance to oxygen levels in bottom waters (Zonneveld et al., 2013), perhaps as a consequence of species-specific sensitivity to low oxygen conditions during excystment.

Several proxies can be used to gain insight in the oxygen content of 

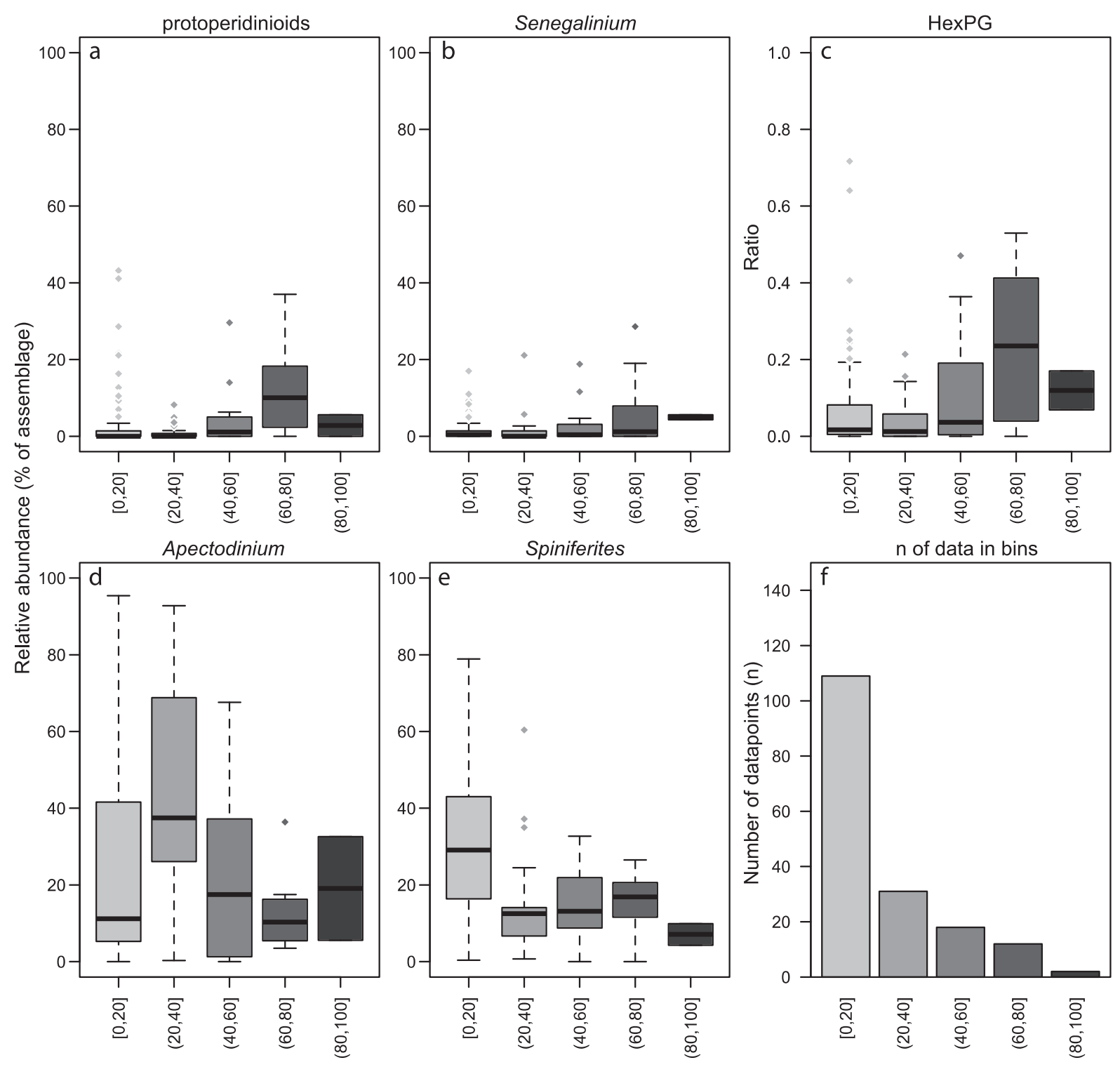

Corg/Ptot (mol/mol ratio)

Fig. 8. Relation of relative abundance of selected ecological groups and HexPG ratio to Corg/Ptot ratio and number of data in each bin.

bottom waters; we here use total organic carbon content (TOCwt $\%$ ) and Corg/Ptot ratio of the sediment, which are both tightly coupled to oxygenation, either directly (Corg/Ptot) or indirectly through productivity and degradation (TOCwt $\%$ ).

The relation between TOC(wt\%) and Senegalinium cpx (Fig. 6a) is perhaps not surprising given its preference for high terrestrial input and nutrient levels (Figs. 4a, 5a). However, some differences exist between genera within this complex (Barke et al., 2011), which may give some clues about the reaction of different genera to oxygen levels. We find that Cerodinium (Fig. 6b) is markedly more abundant at extremely high organic carbon levels ( $>2 \mathrm{wt} \%$ ) than would be expected based on terrestrial input alone. This suggests that this genus was relatively well accommodated to deal with low bottom water oxygen concentrations, despite its presumable benthic stage.

In contrast, both Spiniferites and Apectodinium show higher affinity to lower TOC (Fig. 6d, g), suggesting a preference for well-ventilated bottom waters. For Spiniferites this is consistent with the traditional view of open marine outer neritic affinity (e.g. Sluijs et al., 2008b; Zonneveld et al., 2013). Apectodinium however shows a more surprising trend. Organic carbon concentrations typically increase during the PETM (Sluijs et al., 2006; John et al., 2008; Frieling et al., 2014, 2018b) as does Apectodinium, but we find a weak anti-correlation instead. Along with temperature, such an affinity for slightly higher oxygen concentrations may explain why Apectodinium was not extremely abundant in some localities that show extremely low oxygen conditions during the PETM such as the Arctic (Sluijs et al., 2006) and the West Siberian Sea (Frieling et al., 2014).

The relatively uniform distribution of protoperidinioids with TOC(wt\%) (Fig. 6c), a group that is considered relatively sensitive to oxic degradation (Zonneveld et al., 1997a), shows that preferential oxic degradation of these cysts is unlikely an important factor in our dataset. However, there appears to be an increase in protoperinioids towards higher Corg/Ptot values (Fig. 8a), which may be related to lower oxygen conditions. It should be noted, though, that there are relatively few Corg/Ptot data available and that most of the data are from the PETM of the tropical Atlantic, records that are biased towards high relative abundance of protoperidinioid cysts due to the absence of other taxa. 

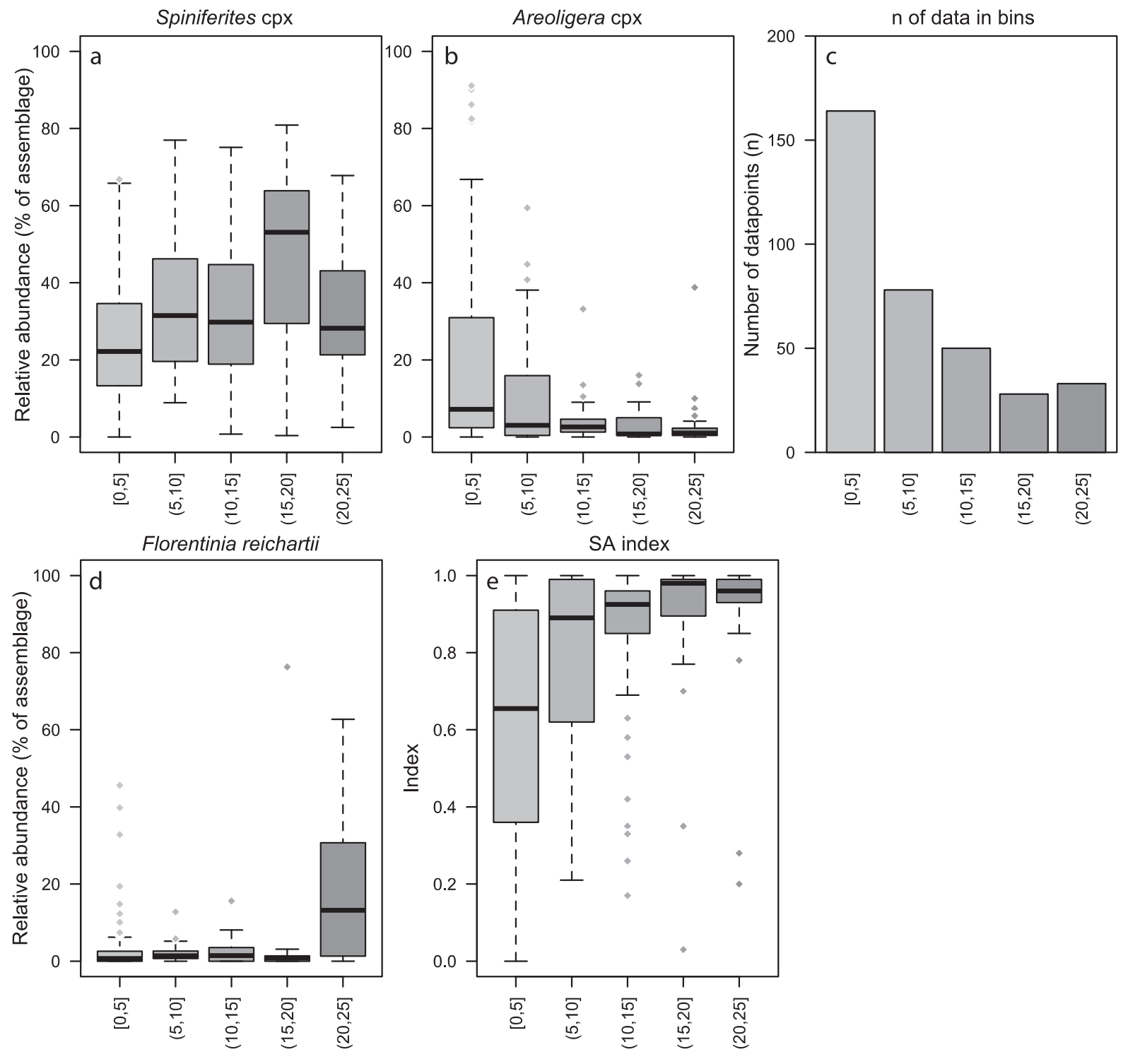

Carbonate (wt\%)

Fig. 9. Relation of relative abundance of selected ecological groups and SA index to sedimentary carbonate content in weight percentage (wt\%) and number of data points in each bin.

\subsection{Shore proximity \& sea level}

Notably, the Areoligera group has been found associated with relatively high-energy environments in the Paleogene (Sluijs et al., 2008b). As a result, an index was derived from the relative abundance of this group to that of Spiniferites, a generalist taxon with a more open marine affinity. These inferences are consistent with carbonate percentage of the sediments. Higher abundances of Areoligera are correlated to lower carbonate and higher amounts of the coarse fraction (Figs. 9b, 10b). The Spiniferites/(Spiniferites + Areoligera (S/A) index was originally formulated to reconstruct sea level fluctuations. However, from a global perspective the variation in the SA index is virtually identical to the relative abundance of Areoligera due to the uniform distribution of Spiniferites (Figs. 9a, 10a). This also implies the SA index is particularly useful to track sea level fluctuations in settings if neither Areoligera nor Spiniferites are major components of the assemblages. Such assemblages may be found in Paleocene pro-delta settings, such as found at ODP Site 1172 (Sluijs et al., 2011), Spitsbergen (Harding et al., 2011) and in the Arctic (Sluijs et al., 2008b), where Areoligera and Spiniferites simultaneously become more common during the PETM because of stronger marine influence. In some open ocean sites, such as the equatorial Atlantic Site 959, the response in Areoligera is similar to that of epicystal Goniodomideae, which become more abundant during periods of increased stratification (Frieling et al., 2018b).

\subsection{Migrations}

Many poleward migrations of species took place during the PETM, including but not limited to mammals, nannoplankton, dinoflagellates, foraminifera and flora (Sluijs et al., 2007b) and most notably in Apectodinium. To expand on the mechanisms behind these migrations, (sub) tropical sections are crucial for elucidating species affinities independently of the PETM. We identify at least three other groups present in the Paleocene and Eocene in the tropics that are found almost exclusively during the PETM at higher latitudes, although relative concentrations are generally much lower (Fig. 11).

Notably, $F$. reichartii shows a minimum temperature requirement around $\sim 30^{\circ} \mathrm{C}$, much higher than that of Apectodinium. During the 

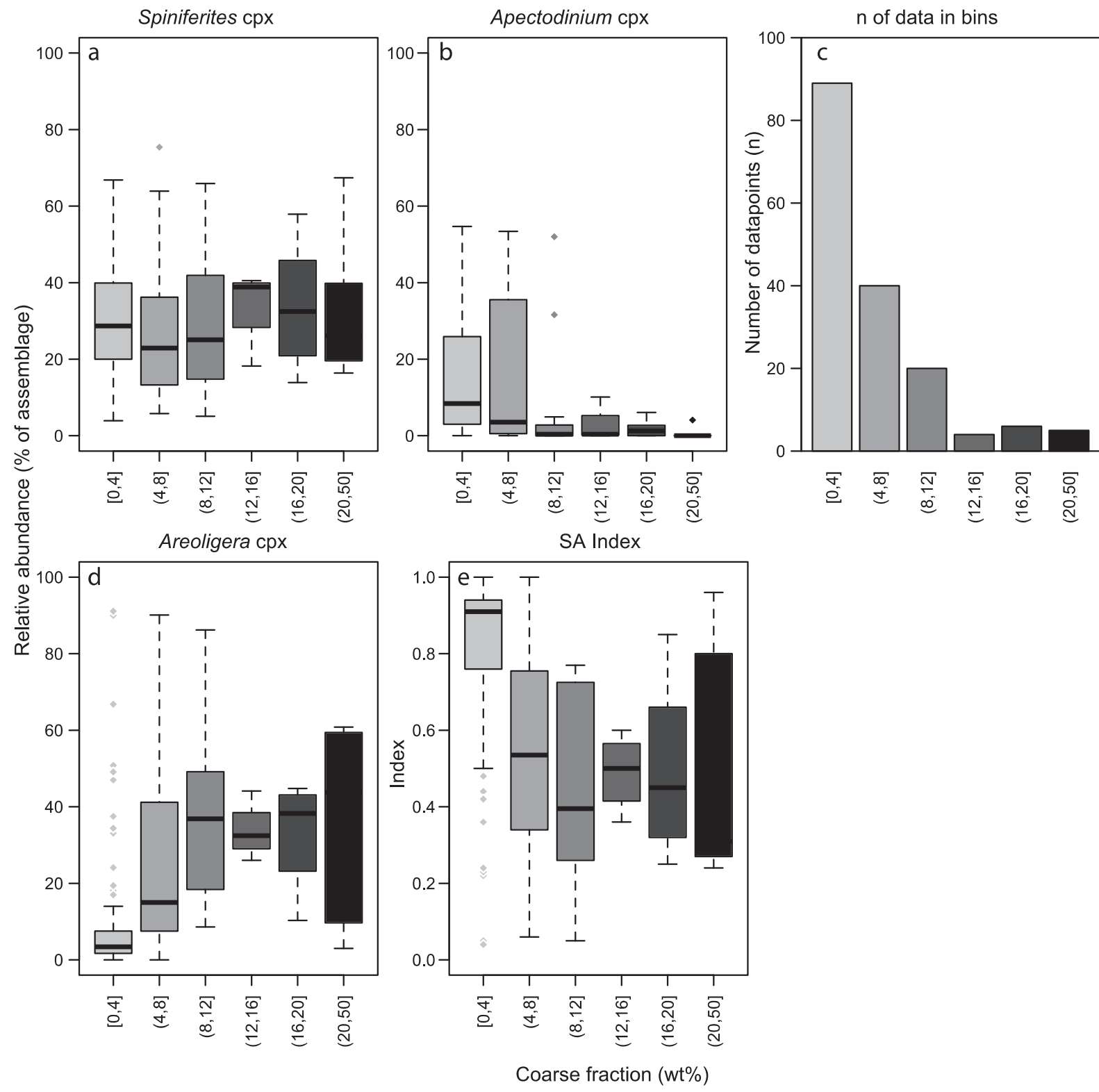

Fig. 10. Relation of relative abundance of selected ecological groups and SA index to coarse fraction ( $>63$ um) and number of data in each bin.

PETM, F. reichartii is found at Bass River and Wilson Lake on the New Jersey Shelf and, remarkably also at Site 1172 in the Southern Ocean and the Otway Basin, Australia (Frieling et al., 2018a), which were located at paleolatitudes between 55 and $60^{\circ} \mathrm{S}$ (van Hinsbergen et al., 2015). The occurrence of $F$. reichartii and its apparent narrow high temperature tolerance (Fig. 3c) may provide additional support for the extremely high temperatures $\left(\sim 30^{\circ} \mathrm{C}\right)$ reconstructed for the southwest Pacific during the PETM (e.g. Sluijs et al., 2011; Hollis et al., 2015). Although additional factors, such as stratification, storminess and nutrient levels may also play a role, a similar temperature driven migration effect is apparent from epicystal Goniodomideae. These occur only during the warmest periods of the Paleogene, the EECO and PETM in the Southern Ocean (Brinkhuis et al., 2003; Sluijs et al., 2011). Similarly, although not as clearly, Hafniasphaera often increases in abundance at higher latitudes during the PETM (Fig. 11c) and this group also shows a positive correlation with temperature (Fig. 3e).

The temperature driven responses implies these groups are potentially suitable to identify high temperature intervals in mid and high latitude sections without the use of additional molecular or isotopic tools. Some caution should be taken as stratification and salinity fluctuations, although likely a result of higher temperatures, were more prevalent during the PETM than during the Paleocene, implying an indirect mechanism to temperature driven migrations may be important.

\section{Conclusions \& outlook}

We present a compilation of environmental proxy data and Paleogene dinocyst assemblages and document ecological preferences of specific dinocyst groups. Binning of the environmental proxy data allows us to semi-quantitatively assess optimal conditions as well as tolerance levels of extinct dinoflagellates for multiple specific ecological parameters. An updated, generalized, view of the affinities obtained with this approach supports many but not all of the previously determined affinities and we identify highly informative affinities of several taxa (Table 3 and Fig. 12). Although it is at this point not possible to distinguish between primary, secondary or even further removed indirect relations, we find strong indications that temperaturedriven migrations in dinoflagellates during the PETM were more common than previously thought. In addition to Apectodinium, epicystal 
a

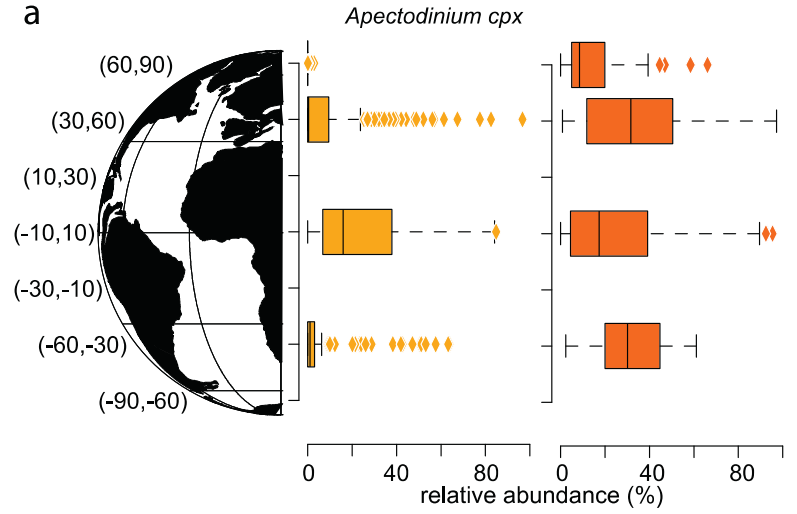

C

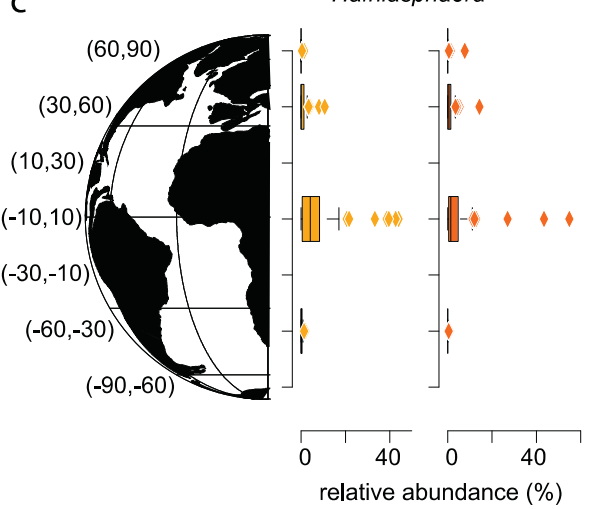

b

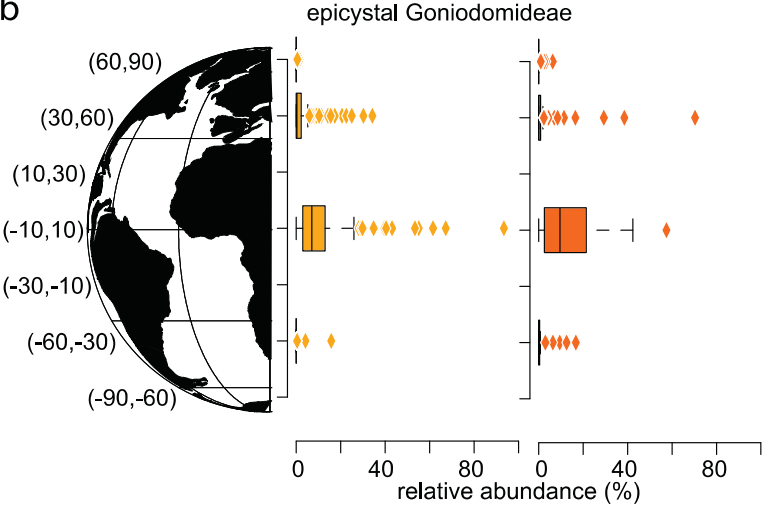

d

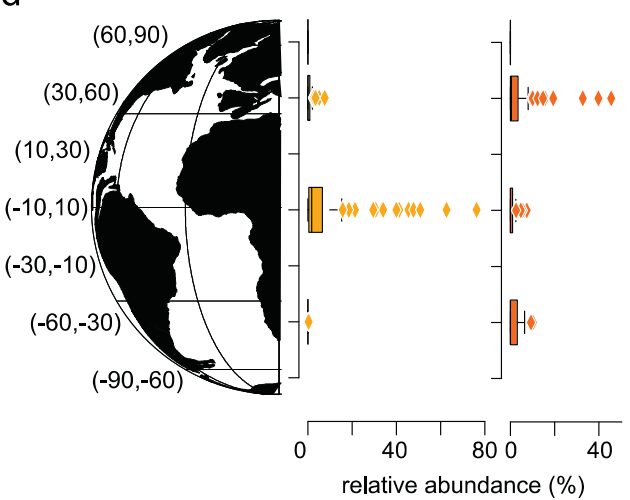

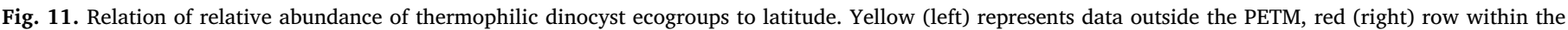

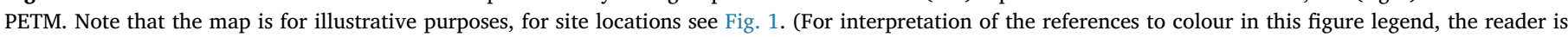
referred to the web version of this article.)

Goniodomideae, Hafniasphaera and F. reichartii and perhaps other species migrated polewards (Fig. 11). This vast latitudinal overhaul in species is also connected to increased stratification and nutrient input, possibly from enhanced run-off.

We further find that specific peridinioids, most notably Cerodinium but possibly also protoperidinioids, may tolerate low bottom water oxygen conditions as evidenced by their relatively high abundance at high TOC content and high Corg/Ptot ratios. In addition, low bottom water oxygen concentrations are often found below high-productivity regions, which matches the occurrence of previously recognized abundances of peridinioid cysts. However, we find that Apectodinium behaves differently from the other peridinioids to terrestrial (nutrient) input and lower oxygen conditions. We therefore speculate that Apectodinium, unlike most other peridinioid cysts was perhaps not an obligate heterotroph, resulting in potential bias in the use of the $P / G$ ratio, an observation that may be supported by the first single-cyst carbon isotope analyses (Sluijs et al., 2018). Therefore the use of HexP over gonyaulacoid ratio as a supplement to the classic $\mathrm{P} / \mathrm{G}$ ratio is advised until the trophic affinity of Apectodinium is resolved.

The identification of paleoecological affinities of fossil dinoflagellates and their cysts originated in the 1960's to 1980's (e.g. Wall and Dale, 1966; Harland, 1973; Brinkhuis and Zachariasse, 1988). The first conceptual model of primary factors determining the abundance at study sites along the transect from coast to open ocean dates from the early 1990's (Brinkhuis, 1994). Building on this work, we have compiled the wealth of information that has become available in the current millennium when dinocyst assemblage studies were directly paired with sedimentological, lithological and geochemical proxies. This has now provided unprecedented detail in our understanding of minimum requirements and optimal conditions for extinct Paleogene taxa
Table 3

Group and species affinities. *** indicates clear affinity, ** likely affinity, * possible affinity. Inferences from other work not tested here (a) (b) and (c).

\begin{tabular}{|c|c|}
\hline Group & Affinity \\
\hline Senegalinium complex & $\begin{array}{l}* * * \text { Low salinity } \\
* * \text { High nutrients } \\
\text { *Low temperature? }\end{array}$ \\
\hline Protoperidinioids & $\begin{array}{l}* * * \text { High nutrients } \\
* * \text { Prey species (a) } \\
\text { *High temperature? } \\
\text { *Upwelling (b) }\end{array}$ \\
\hline Apectodinium complex & $* * *$ High temperature \\
\hline Epicystal Goniodomideae & $\begin{array}{l}* * * \text { High temperature } \\
* * \text { Stratification } \\
* \text { Fluctuating salinity }\end{array}$ \\
\hline Spiniferites complex & $\begin{array}{l}\text { *Low nutrients } \\
\text { *Open marine }\end{array}$ \\
\hline Hafniasphaera & $* *$ High temperature \\
\hline Hystrichosphaeridium & $* *$ Low temperature \\
\hline Cordosphaeridium complex complex & $\begin{array}{l}\text { *Open Marine? } \\
\text { *High temperature? }\end{array}$ \\
\hline Diphyes & $?$ \\
\hline Florentinia reichartii & $\begin{array}{l}* * * \text { Very high temperature } \\
* \text { Open marine }\end{array}$ \\
\hline Other proximal gonyaulacoid cysts & *Below marine salinity \\
\hline Apical archaeopyle & *High terrestrial input \\
\hline $\begin{array}{l}\text { Other proximal gonyaulacoid cysts } \\
\text { Precingular archaeopyle }\end{array}$ & *Open marine \\
\hline Impagidinium & $* * *$ Oceanic $(\mathrm{c})$ \\
\hline Areoligera complex & $\begin{array}{l}\text { *Proximal systems } \\
\text { *Low terrestrial input } \\
\text { *Normal Salinity }\end{array}$ \\
\hline
\end{tabular}




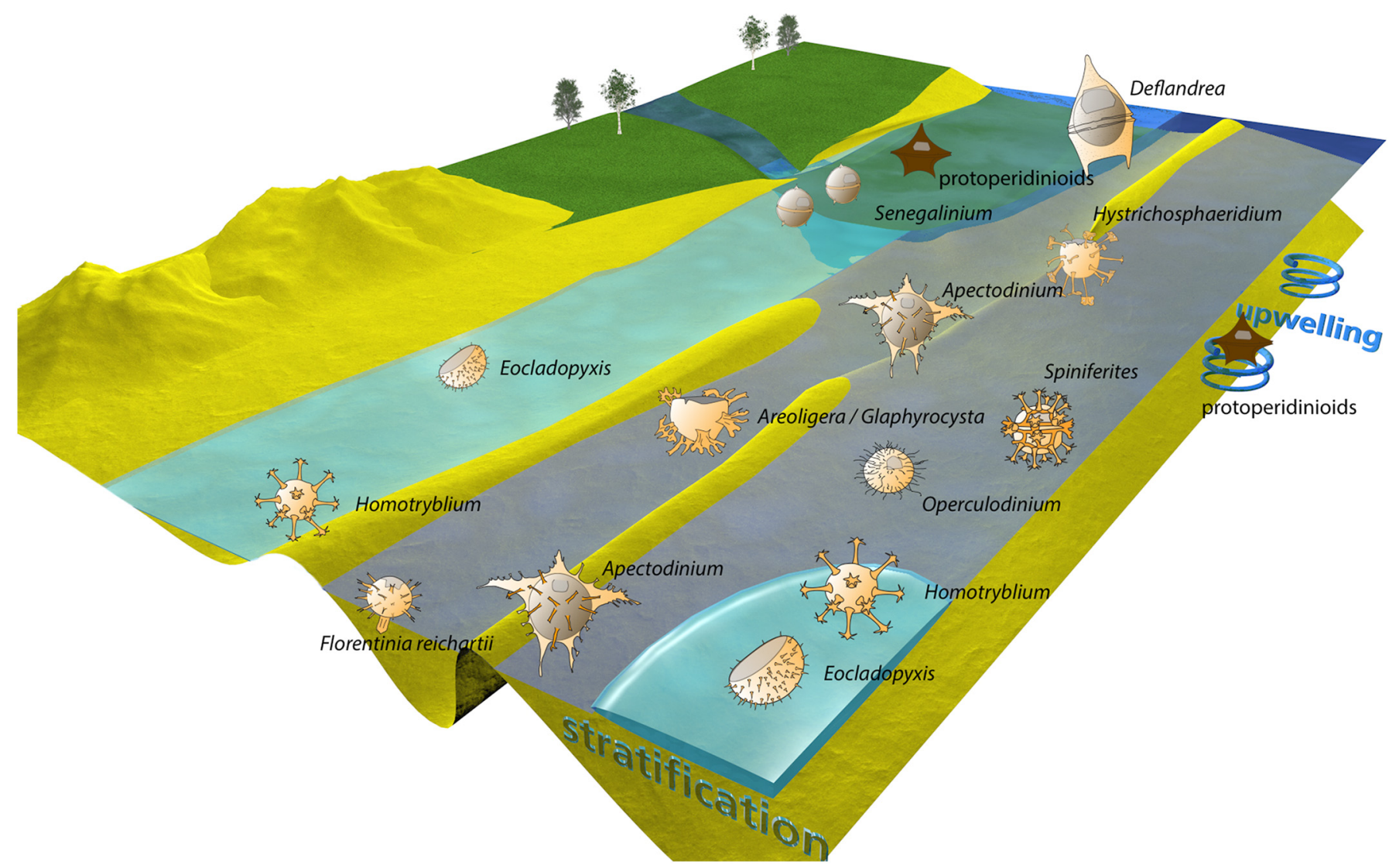

Fig. 12. Schematic view of paleoecological affinities of dominant Paleocene-Eocene dinocyst groups, genera and species. See also Table 3.

(Figs. 3-10, summarized in Fig. 12 and Table 3). The approach introduced here is ideally suited for re-analyses with the availability of new data to further refine these insights.

The results of this work also show that the integration of microfossil assemblage studies with reconstructions of geochemical, oceanographic and physical parameters obtained from sedimentary archives provides a unique tool to assess the ecology of extinct taxa. A database such as we exemplify here may be constructed for any time period for which decent geographical coverage exists, and any (micro)fossil group both in modern, recent past and geological deep time and, crucially, this then allows for a more quantitative assessment of other records. This therefore presents a relatively simple option to increase and ensure the value of existing and forthcoming microfossil work.

\section{Acknowledgments}

We greatly value contributions from the different scientific communities providing high quality proxy and dinoflagellate cyst assemblage data, which provided the foundations for this work. In particular, we thank Henk Brinkhuis, whose work and inspiration has provided the basis of our dinocyst work and its integration with other types of proxy data. Moreover, we are very grateful to 2 anonymous reviewers who invested their time to write detailed reviews of this work and provide highly useful and constructive comments.

We used samples and data provided by the International Ocean Discovery Program (IODP) and its predecessor, the Ocean Drilling Program. This contribution was funded through European Research Council (ERC) starting grant \#259627 and Netherlands Organization for Scientific Research (NWO) grant \#ALWOP.223, both to AS. This work was carried out under the program of the Netherlands Earth System Science Centre (NESSC), financially supported by the Dutch Ministry of Education, Culture and Science.

\section{Data availability}

All proxy and assemblage data used in this contribution are made available through the online database Pangaea (https://doi.pangaea. de/10.1594/PANGAEA.893291).

\section{References}

Alldredge, A.L., Passow, U., Haddock, H.D., 1998. The characteristics and transparent exopolymer particle (TEP) content of marine snow formed from thecate dinoflagellates. J. Plankton Res. 20 (3), 393-406.

Anderson, D.M., Kulis, D.M., Binder, B.J., 1984. Sexuality and cyst formation in the dinoflagellate Gonyaulax tamarensis: cyst yield in batch cultures. J. Phycol. 20 (3), 418-425.

Anderson, D.M., Coats, D.W., Tyler, M.A., 1985. Encystment of the dinoflagellate Gyrodinium uncatenum: temperature and nutrient effects. J. Phycol. 21 (2), 200-206.

Anderson, D.M., Taylor, C.D., Armbrust, E.V., 1987. The effects of darkness and anaerobiosis on dinoflagellate cyst germination. Limnol. Oceanogr. 32 (2), 340-351. https://doi.org/10.4319/10.1987.32.2.0340.

Barke, J., Abels, H.A., Sangiorgi, F., Greenwood, D.R., Sweet, A.R., Donders, T., Reichart, G.-J., Lotter, A.F., Brinkhuis, H., 2011. Orbitally forced Azolla blooms and middle Eocene arctic hydrology: clues from palynology. Geology 39 (5), 427-430. https:// doi.org/10.1130/G31640.1.

Barke, J., van der Burgh, J., van Konijnenburg-van Cittert, J.H.A., Collinson, M.E., Pearce, M.A., Bujak, J., Heilmann-Clausen, C., Speelman, E.N., van Kempen, M.M.L., Reichart, G.-J., Lotter, A.F., Brinkhuis, H., 2012. Coeval Eocene blooms of the freshwater fern Azolla in and around Arctic and Nordic seas. Palaeogeogr. Palaeoclimatol. Palaeoecol. 337-338, 108-119. https://doi.org/10.1016/j.palaeo. 2012.04.002.

Bijl, P.K., Schouten, S., Sluijs, A., Reichart, G.-J., Zachos, J.C., Brinkhuis, H., 2009. Early Palaeogene temperature evolution of the Southwest Pacific Ocean. Nature 461 (7265), 776-779. https://doi.org/10.1038/nature08399.

Bijl, P.K., Sluijs, A., Brinkhuis, H., 2013a. A magneto- and chemostratigraphically calibrated dinoflagellate cyst zonation of the early Palaeogene South Pacific Ocean. Earth-Sci. Rev. 124 (0), 1-31. https://doi.org/10.1016/j.earscirev.2013.04.010.

Bijl, P.K., Bendle, J.A.P., Bohaty, S.M., Pross, J., Schouten, S., Tauxe, L., Stickley, C.E., McKay, R.M., Rohl, U., Olney, M., Sluijs, A., Escutia, C., Brinkhuis, H., Klaus, A., Fehr, A., Williams, T., Carr, S.A., Dunbar, R.B., Gonzalez, J.J., Hayden, T.G., Iwai, M., Jimenez-Espejo, F.J., Katsuki, K., Kong, G.S., Nakai, M., Passchier, S., Pekar, S.F., Riesselman, C., Sakai, T., Shrivastava, P.K., Sugisaki, S., Tuo, S., van de Flierdt, T., 
Welsh, K., Yamane, M., 2013b. Eocene cooling linked to early flow across the Tasmanian Gateway. Proc. Natl. Acad. Sci. 110 (24), 9645-9650. https://doi.org/10. $1073 /$ pnas. 1220872110

Blanco, J., 1995. Cyst production in four species of neritic dinoflagellates. J. Plankton Res. 17 (1), 165-182.

Bogus, K., Harding, I.C., King, A., Charles, A.J., Zonneveld, K.A.F., Versteegh, G.J.M., 2012. The composition and diversity of dinosporin in species of the Apectodinium complex (Dinoflagellata). Rev. Palaeobot. Palynol. 183, 21-31. https://doi.org/10. 1016/j.revpalbo.2012.07.001.

Bogus, K., Mertens, K.N., Lauwaert, J., Harding, I.C., Vrielinck, H., Zonneveld, K.A.F., Versteegh, G.J.M., 2014. Differences in the chemical composition of organic-walled dinoflagellate resting cysts from phototrophic and heterotrophic dinoflagellates. J. Phycol. 50 (2), 254-266.

Brinkhuis, H., 1994. Late Eocene to early Oligocene dinoflagellate cysts from the Priabonian type-area (Northeast Italy): Biostratigraphy and paleoenvironmental interpretation. Palaeogeogr. Palaeoclimatol. Palaeoecol. 107 (1-2), 121-163.

Brinkhuis, H., Zachariasse, W.J., 1988. Dinoflagellate cysts, sea level changes and planktonic foraminifers across the Cretaceous-Tertiary boundary at El Haria, Northwest Tunisia. Mar. Micropaleontol. 13 (2), 153-191. https://doi.org/10.1016/ 0377-8398(88)90002-3.

Brinkhuis, H., Bujak, J.P., Smit, J., Versteegh, G.J.M., Visscher, H., 1998. Dinoflagellatebased sea surface temperature reconstructions across the Cretaceous-Tertiary boundary. Palaeogeogr. Palaeoclimatol. Palaeoecol. 141 (1), 67-83.

Brinkhuis, H., Sengers, S., Sluijs, A., Warnaar, J., Williams, G.L., Exon, N.F., 2003. Latest creataceous-earliest Oligocene and quaternary dinoflagellate cysts, ODP Site 1172, East Tasman Plateau. Proc. Ocean Drill. Program Sci. Results 189 (October), 48.

Brinkhuis, H., Schouten, S., Collinson, M.E., Sluijs, A., Sinninghe Damsté, J.S., Dickens, G.R., Huber, M., Cronin, T.M., Onodera, J., Takahashi, K., Bujak, J.P., Stein, R., van der Burgh, J., Eldrett, J.S., Harding, I.C., Lotter, A.F., Sangiorgi, F., van Konijnenburg-van Cittert, H., de Leeuw, J.W., Matthiessen, J., Backman, J., Moran, K., 2006. Episodic fresh surface waters in the Eocene Arctic Ocean. Nature 441 (7093), 606-609. https://doi.org/10.1038/nature04692.

Bujak, J.P., Brinkhuis, H., 1998. Global warming and dinocyst changes across the Paleocene/Eocene epoch boundary. In: Aubry, M.-P., Lucas, S., Berggren, W.A. (Eds.), Late Paleocene-Early Eocene Biotic and Climatic Events in the Marine and Terrestrial Records. Columbia University Press, pp. 277-295.

Bursa, A., 1963. Phytoplankton in coastal waters of the Arctic Ocean at Point Barrow, Alaska. Arctic 16 (4), 239-262.

Cramwinckel, M.J., Huber, M., Kocken, I.J., Agnini, C., Bijl, P.K., Bohaty, S.M., Frieling, J., Goldner, A., Hilgen, F.J., Kip, E.L., Peterse, F., van der Ploeg, R., Röhl, U., Schouten, S., Sluijs, A., 2018. Synchronous tropical and polar temperature evolution in the Eocene. Nature 559 (7714), 382-386. https://doi.org/10.1038/s41586-0180272-2.

Crouch, E.M., Brinkhuis, H., 2005. Environmental change across the Paleocene-Eocene transition from eastern New Zealand: a marine palynological approach. Mar. Micropaleontol. 56 (3), 138-160.

Crouch, E.M., Heilmann-Clausen, C., Brinkhuis, H., Morgans, H.E.G., Rogers, K.M., Egger, H., Schmitz, B., 2001. Global dinoflagellate event associated with the late Paleocene thermal maximum. Geology 29 (4), 315-318.

Crouch, E.M., Dickens, G.R., Brinkhuis, H., Aubry, M.-P., Hollis, C.J., Rogers, K.M., Visscher, H., 2003. The Apectodinium acme and terrestrial discharge during the Paleocene-Eocene thermal maximum: new palynological, geochemical and calcareous nannoplankton observations at Tawanui, New Zealand. Palaeogeogr. Palaeoclimatol. Palaeoecol. 194 (4), 387-403.

Dale, B., 1983. Dinoflagellate resting cysts: "benthic plankton". In: Fryxell, G.A. (Ed.), Survival Strategies of the Algae. Cambridge University Press, pp. 69-136.

Dale, B., 1996. Dinoflagellate cyst ecology: modeling and geological applications. In: Jansonius, J., McGregor, D.C. (Eds.), Palynology Principles and Application. 3. American Association of Stratigraphic Palynologists Foundation, pp. 1249-1275.

Dale, B., 2009. Eutrophication signals in the sedimentary record of dinoflagellate cysts in coastal waters. J. Sea Res. 61 (1), 103-113.

Dale, B. and Dale, A. L.: Dinoflagellate Contributions to The Deep Sea, Woods Hole Oceanographic Institution, Ocean and Biocoenosis Series 5, 85 pp, 1992.

Dale, B., Fjellså, A., 1994. Dinoflagellate cysts as paleoproductivity indicators: state of the art, potential, and limits. In: Carbon Cycling in the Glacial Ocean: Constraints on the Ocean's Role in Global Change. Springer, pp. 521-537.

Datema, M., Sangiorgi, F., de Vernal, A., Reichart, G. J., Lourens, L. J. and Sluijs, A.: Comparison of qualitative and quantitative dinoflagellate cyst approaches in reconstructing glacial-interglacial climate variability at West Iberian margin IODP 'Shackleton' Site U1385, Mar. Micropaleontol., 136(August), 14-29, doi:https://doi. org/10.1016/j.marmicro.2017.08.003, 2017.

de Souza, K.B., Jephson, T., Hasper, T.B., Carlsson, P., 2014. Species-specific dinoflagellate vertical distribution in temperature-stratified waters. Mar. Biol. 161 (8), 1725-1734. https://doi.org/10.1007/s00227-014-2446-2.

De Vernal, A., Eynaud, F., Henry, M., Hillaire-Marcel, C., Londeix, L., Mangin, S., Matthiessen, J., Marret, F., Radi, T., Rochon, A., Solignac, S., Turon, J.L., 2005. Reconstruction of sea-surface conditions at middle to high latitudes of the Northern Hemisphere during the Last Glacial Maximum (LGM) based on dinoflagellate cyst assemblages. Quat. Sci. Rev. 24 (7), 897-924. https://doi.org/10.1016/j.quascirev. 2004.06.014.

Dickens, G.R., O'Neil, J.R., Rea, D.K., Owen, R.M., 1995. Dissociation of oceanic methane hydrate as a cause of the carbon isotope excursion at the end of the Paleocene. Paleoceanography 10 (6), 965-971. https://doi.org/10.1029/95PA02087.

Dickson, A.J., Cohen, A.S., Coe, A.L., 2012. Seawater oxygenation during the PaleoceneEocene thermal Maximum. Geology 40 (7), 639-642. https://doi.org/10.1130/ G32977.1.
Donders, T.H., Weijers, J.W.H., Munsterman, D.K., Kloosterboer-van Hoeve, M.L., Buckles, L.K., Pancost, R.D., Schouten, S., Sinninghe Damsté, J.S., Brinkhuis, H., 2009. Strong climate coupling of terrestrial and marine environments in the Miocene of Northwest Europe. Earth Planet. Sci. Lett. 281 (3-4), 215-225. https://doi.org/10. 1016/j.epsl.2009.02.034.

Dunkley Jones, T., Lunt, D.J., Schmidt, D.N., Ridgwell, A.J., Sluijs, A., Valdes, P.J., Maslin, M.A., 2013. Climate model and proxy data constraints on ocean warming across the Paleocene-Eocene thermal Maximum. Earth-Sci. Rev. 125 (0), 123-145. https://doi.org/10.1016/j.earscirev.2013.07.004.

Egger, H., Fenner, J., Heilmann-Clausen, C., Rogl, F., Sachsenhofer, R., Schmitz, B., 2003. Paleoproductivity of the northwestern Tethyan margin (Anthering section, Austria) across the Paleocene-Eocene transition, Spec. Pap. 369 Causes consequences. Glob. Warm Clim. Early Paleogene 369 (0), 133-146. https://doi.org/10.1130/0-8137. 2369-8.133.

Eldrett, J.S., Greenwood, D.R., Polling, M., Brinkhuis, H., Sluijs, A., 2014. A seasonality trigger for carbon injection at the Paleocene-Eocene Thermal Maximum. Clim. Past 10 (2), 759-769.

Ellegaard, M., Lewis, J., Harding, I.C., 2002. Cyst-theca relationship, life cycle, and effects of temperature and salinity on the cyst morphology of Gonyaulax baltica sp. nov. (Dinophyceae) from the Baltic Sea area. J. Phycol. 38 (4), 775-789.

Evitt, W. R.: Sporopollenin Dinoflagellate Cysts: Their Morphology and Interpretation, American Association of Stratigraphic Palynologists Foundation, 333p. 1985.

Fensome, R., Taylor, F.J.R., Norris, G., Sarjeant, W.A.S., Wharton, D.I., Williams, G.L., 1993. A classification of living and fossil dinoflagellates. Micropalaeontology Special vo, 1-245

Fensome, R.A., Riding, J.B., Taylor, F.J.R., 1996. In: Jansonius, J., McGregor, D.C. (Eds.), Dinoflagellates, in Palynology: Principles and Applications. American Association of Stratigraphic Palynologists Foundation, pp. 107-169.

Finkel, Z.V., Sebbo, J., Feist-Burkhardt, S., Irwin, A.J., Katz, M.E., Schofield, O.M.E. Young, J.R., Falkowski, P.G., 2007. A universal driver of macroevolutionary change in the size of marine phytoplankton over the Cenozoic. Proc. Natl. Acad. Sci. 104 (51), 20416-20420. https://doi.org/10.1073/pnas.0709381104.

Firth, J.V., 1996. Upper middle Eocene to Oligocene dinoflagellate biostratigraphy and assemblage variations in Hole 913B, Greenland Sea. In: Proceedings of the Ocean Drilling Program. Scientific Results. vol. 151. Ocean Drilling Program, pp. 203-242.

Frieling, J., Iakovleva, A.I., Reichart, G.-J., Aleksandrova, G.N., Gnibidenko, Z.N., Schouten, S., Sluijs, A., 2014. Paleocene-Eocene warming and biotic response in the epicontinental West Siberian Sea. Geology 42 (9), 767-770.

Frieling, J., Gebhardt, H., Huber, M., Adekeye, O.A., Akande, S.O., Reichart, G.-J., Middelburg, J.J., Schouten, S., Sluijs, A., 2017. Extreme warmth and heat-stressed plankton in the tropics during the Paleocene-Eocene Thermal Maximum. Sci. Adv. 3 (3), e1600891. https://doi.org/10.1126/sciadv.1600891.

Frieling, J., Huurdeman, E.P., Rem, C.C.M., Donders, T.H., Pross, J., Bohaty, S.M., Holdgate, G.R., Gallagher, S.J., McGowran, B., Bijl, P.K., 2018a. Identification of the Paleocene-Eocene boundary in coastal strata in the Otway Basin, Victoria, Australia. J. Micropalaeontol. 37 (1), 317-339. https://doi.org/10.5194/jm-37-317-2018.

Frieling, J., Reichart, G.-J., Middelburg, J.J., Röhl, U., Westerhold, T., Bohaty, S.M., Sluijs, A., 2018b. Tropical Atlantic climate and ecosystem regime shifts during the Paleocene-Eocene Thermal Maximum. Clim. Past 14 (1), 39-55. https://doi.org/10. 5194/cp-14-39-2018.

Gradstein, F.M., Ogg, J.G., Schmitz, M., Ogg, G., 2012. The Geologic Time Scale 20122 Volume Set. Elsevier.

Guasti, E., Kouwenhoven, T.J., Brinkhuis, H., Speijer, R.P., 2005. Paleocene Sea-level and productivity changes at the southern Tethyan margin (El Kef, Tunisia). Mar. Micropaleontol. 55, 1-2), 1-17.

Harding, I. C., Charles, A. J., Marshall, J. E. A., Pälike, H., Roberts, A. P., Wilson, P. A., Jarvis, E., Thorne, R., Morris, E., Moremon, R., Pearce, R. B. and Akbari, S.: Sea-level and salinity fluctuations during the Paleocene-Eocene thermal maximum in Arctic Spitsbergen, Earth Planet. Sci. Lett., 303(1-2), 97-107, doi:http://dx.doi.org/10. 1016/j.epsl.2010.12.043, 2011.

Harland, R., 1973. Dinoflagellate cysts and acritarchs from the Bearpaw Formation (Upper Campanian) of southern Alberta. Canada., Palaeontology 16 (4), 665-706.

Harland, R., 1983. Distribution maps of recent dinoflagellate cysts in bottom sediments from the North-Atlantic Ocean and adjacent seas. Palaeontology 26 (MAY), 321-387.

Head, M.J., 1996. Modern dinoflagellate cysts and their biological affinities. In: Jansonius, J., McGregor, D.C. (Eds.), Palynology Principles and Application. 3. American Association of Stratigraphic Palynologists Foundation, pp. 1197-1248.

Hoins, M., Van de Waal, D.B., Eberlein, T., Reichart, G.-J., Rost, B., Sluijs, A., 2015. Stable carbon isotope fractionation of organic cyst-forming dinoflagellates: evaluating the potential for a CO2 proxy. Geochim. Cosmochim. Acta 160, 267-276. https://doi. org/10.1016/j.gca.2015.04.001.

Hollis, C.J., Hines, B.R., Littler, K., Villasante-Marcos, V., Kulhanek, D.K., Strong, C.P., Zachos, J.C., Eggins, S.M., Northcote, L., Phillips, A., 2015. The Paleocene-Eocene Thermal Maximum at DSDP Site 277, Campbell Plateau, Southern Pacific Ocean. Clim. Past 11 (7), 1009-1025. https://doi.org/10.5194/cp-11-1009-2015.

Hopmans, E.C., Weijers, J.W.H., Schefuß, E., Herfort, L., Sinninghe Damsté, J.S. Schouten, S., 2004. A novel proxy for terrestrial organic matter in sediments based on branched and isoprenoid tetraether lipids. Earth Planet. Sci. Lett. 224 (1-2), 107-116. https://doi.org/10.1016/j.epsl.2004.05.012.

Houben, A.J.P., Bijl, P.K., Pross, J., Bohaty, S.M., Passchier, S., Stickley, C.E., Rohl, U., Sugisaki, S., Tauxe, L., van de Flierdt, T., Olney, M., Sangiorgi, F., Sluijs, A., Escutia, C., Brinkhuis, H., 2013. Reorganization of Southern Ocean plankton ecosystem at the onset of Antarctic glaciation. Science 340 (6130), 341-344. https://doi.org/10.1126/ science. 1223646

Iakovleva, A.I., Brinkhuis, H., Cavagnetto, C., 2001. Late Palaeocene-Early Eocene di noflagellate cysts from the Turgay Strait, Kazakhstan; correlations across ancient 
seaways. Palaeogeogr. Palaeoclimatol. Palaeoecol. 172 (3), 243-268.

Ingall, E.D., Van Cappellen, P., 1990. Relation between sedimentation rate and burial of organic phosphorus and organic carbon in marine sediments. Geochim. Cosmochim. Acta 54 (2), 373-386.

Inglis, G.N., Farnsworth, A., Lunt, D.J., Foster, G.L., Hollis, C.J., Pagani, M., Jardine, P.E., Pearson, P.N., Markwick, P.J., Galsworthy, A.M.J., Raynham, L., Taylor, K.W.R., Pancost, R.D., 2015. Descent towards the Icehouse: Eocene Sea surface cooling inferred from GDGT distributions. Paleoceanography 30 (7), 1000-1020. https://doi. org/10.1002/2014PA002723.

Janouškovec, J., Gavelis, G.S., Burki, F., Dinh, D., Bachvaroff, T.R., Gornik, S.G., Bright, K.J., Imanian, B., Strom, S.L., Delwiche, C.F., Waller, R.F., Fensome, R.A., Leander, B.S., Rohwer, F.L., Saldarriaga, J.F., 2017. Major transitions in dinoflagellate evolution unveiled by phylotranscriptomics. Proc. Natl. Acad. Sci. 114 (2), E171-E180. https://doi.org/10.1073/pnas.1614842114.

Jephson, T., Carlsson, P., Fagerberg, T., 2012. Dominant impact of water exchange and disruption of stratification on dinoflagellate vertical distribution. Estuar. Coast. Shelf Sci. 112, 198-206. https://doi.org/10.1016/j.ecss.2012.07.020.

John, C.M., Bohaty, S.M., Zachos, J.C., Sluijs, A., Gibbs, S.J., Brinkhuis, H., Bralower, T.J., 2008. North American continental margin records of the Paleocene-Eocene thermal maximum: implications for global carbon and hydrological cycling. Paleoceanography 23 (2), 1-20. https://doi.org/10.1029/2007PA001465.

Keafer, B.A., Buesseler, K.O., Anderson, D.M., 1992. Burial of living dinoflagellate cysts in estuarine and nearshore sediments. Mar. Micropaleontol. 20 (2), 147-161. https:// doi.org/10.1016/0377-8398(92)90004-4.

Kender, S., Stephenson, M.H., Riding, J.B., Leng, M.J., Knox, R.W.O.B., Peck, V.L., Kendrick, C.P., Ellis, M.A., Vane, C.H., Jamieson, R., 2012. Marine and terrestrial environmental changes in NW Europe preceding carbon release at the PaleoceneEocene transition. Earth Planet. Sci. Lett. 353-354, 108-120. https://doi.org/10. 1016/j.epsl.2012.08.011.

Kodrans-Nsiah, M., De Lange, G.J., Zonneveld, K.A.F., 2008. A natural exposure experiment on short-term species-selective aerobic degradation of dinoflagellate cysts. Rev. Palaeobot. Palynol. 152 (1), 32-39.

Kokinos, J.P., Anderson, D.M., 1995. Morphological development of resting cysts in cultures of the marine dinoflagellate Lingulodinium polyedrum $(=$ L. machaer ophorum). Palynology 19 (1), 143-166. https://doi.org/10.1080/01916122.1995. 9989457.

Kopp, R.E., Schumann, D., Raub, T.D., Powars, D.S., Godfrey, L.V., Swanson-Hysell, N.L., Maloof, A.C., Vali, H., 2009. An Appalachian Amazon? Magnetofossil evidence for the development of a tropical river-like system in the mid-Atlantic United States during the Paleocene-Eocene thermal maximum. Paleoceanography 24 (4), 1-17. https://doi.org/10.1029/2009PA001783.

MacRae, R.A., Fensome, R.A., Williams, G.L., 1996. Fossil dinoflagellate diversity, originations, and extinctions and their significance. Can. J. Bot. 74 (11), 1687-1694.

Marret, F., 1994. Distribution of dinoflagellate cysts in recent marine sediments from the east Equatorial Atlantic (Gulf of Guinea). Rev. Palaeobot. Palynol. 84, 1), 1-22. https://doi.org/10.1016/0034-6667(94)90038-8.

Matthiessen, J., de Vernal, A., Head, M.J., Okolodkov, Y., Zonneveld, K.A.F., Harland, R., 2005. Modern organic-walled dinoflagellate cysts in Arctic marine environments and their (paleo-) environmental significance. Paläontol. Z. 79 (1), 3-51. https://doi.org/ 10.1007/BF03021752.

McCabe, G.J., Clark, M.P., Serreze, M.C., 2001. Trends in Northern Hemisphere surface cyclone frequency and intensity. J. Clim. 14 (12), 2763-2768. https://doi.org/10. 1175/1520-0442(2001)014<2763:TINHSC > 2.0.CO;2.

Mertens, K.N., Ribeiro, S., Bouimetarhan, I., Caner, H., Combourieu Nebout, N., Dale, B., De Vernal, A., Ellegaard, M., Filipova, M., Godhe, A., Goubert, E., Grøsfjeld, K., Holzwarth, U., Kotthoff, U., Leroy, S.A.G., Londeix, L., Marret, F., Matsuoka, K., Mudie, P.J., Naudts, L., Peña-Manjarrez, J.L., Persson, A., Popescu, S.M., Pospelova, V., Sangiorgi, F., van der Meer, M.T.J., Vink, A., Zonneveld, K.A.F., Vercauteren, D., Vlassenbroeck, J., Louwye, S., Nebout, N.C., Dale, B., De Vernal, A., Ellegaard, M., Filipova, M., Godhe, A., 2009. Process length variation in cysts of a dinoflagellate, Lingulodinium machaerophorum, in surface sediments: investigating its potential as salinity proxy. Mar. Micropaleontol. 70 (1), 54-69. https://doi.org/10.1016/j marmicro.2008.10.004.

Montresor, M., Nuzzo, L., Mazzocchi, M.G., 2003. Viability of dinoflagellate cysts after the passage through the copepod gut. J. Exp. Mar. Biol. Ecol. 287 (2), 209-221. https://doi.org/10.1016/S0022-0981(02)00549-X.

Mudie, P.J., 1996. Pellets of dinoflagellate-eating zooplankton. Palynol. Princ. Appl. Found. 1087-1089.

Murphy, B.H., Farley, K., Zachos, J.C., 2010. An extraterrestrial 3 He-based timescale for the Paleocene-Eocene thermal maximum (PETM) from Walvis Ridge, IODP Site 1266. Geochim. Cosmochim. Acta 74 (17), 5098-5108.

Nagai, S., Matsuyama, Y., Oh, S.-J., Itakura, S., 2004. Effect of nutrients and temperature on encystment of the toxic dinoflagellate Alexandrium tamarense (Dinophyceae) Plankt. Biol.Ecol 51 (2), 103-109.

Naustvoll, L.-J., 2000. Prey size spectra and food preferences in thecate heterotrophic dinoflagellates. Phycologia 39 (3), 187-198.

Pagani, M., Pedentchouk, N., Huber, M., Sluijs, A., Schouten, S., Brinkhuis, H., Sinninghe Damsté, J.S., Dickens, G.R., 2006. Arctic hydrology during global warming at the Palaeocene/Eocene thermal maximum. Nature 442 (7103), 671-675. https://doi. org/10.1038/nature05043.

Peña-Manjarrez, J.L., Helenes, J., Gaxiola-Castro, G., Orellana-Cepeda, E., 2005. Dinoflagellate cysts and bloom events at todos Santos Bay, Baja California, Mexico, 1999-2000. Cont. Shelf Res. 25 (11), 1375-1393. https://doi.org/10.1016/j.csr. 2005.02.002.

Penaud, A., Eynaud, F., Turon, J.L., Blamart, D., Rossignol, L., Marret, F., Lopez-Martinez, C., Grimalt, J.O., Malaizé, B., Charlier, K., 2010. Contrasting paleoceanographic conditions off Morocco during Heinrich events (1 and 2) and the last Glacial Maximum. Quat. Sci. Rev. 29 (15-16), 1923-1939. https://doi.org/10.1016/j quascirev.2010.04.011.

Penman, D.E., Hönisch, B., Zeebe, R.E., Thomas, E., Zachos, J.C., 2014. Rapid and sustained surface ocean acidification during the Paleocene-Eocene Thermal Maximum. Paleoceanography 29 (5), 357-369.

Powell, A.J., Brinkhuis, H., Bujak, J.P., 1996. Upper Paleocene-lower Eocene dinoflagellate cyst sequence biostratigraphy of Southeast England. Geol. Soc. Spec. Publ. $101,145-183$.

Pross, J., Brinkhuis, H., 2005. Organic-walled dinoflagellate cysts as paleoenvironmental indicators in the Paleogene; a synopsis of concepts. Paläontol. Z. 79 (1), 53-59.

Radi, T., de Vernal, A., 2008. Dinocysts as proxy of primary productivity in mid-high latitudes of the Northern Hemisphere. Mar. Micropaleontol. 68 (1-2), 84-114. https://doi.org/10.1016/j.marmicro.2008.01.012.

Raffi, I., Backman, J., Zachos, J.C., Sluijs, A., 2009. The response of calcareous nannofossil assemblages to the Paleocene Eocene Thermal Maximum at the Walvis Ridge in the South Atlantic. Mar. Micropaleontol. 70 (3-4), 201-212.

Reid, P.C., Boalch, G.T., 1987. A new method for the identification of dinoflagellate cysts. J. Plankton Res. 9 (1), 249-253.

Rochon, A., Lewis, J., Ellegaard, M., Harding, I.C., 2009. The Gonyaulax spinifera (Dinophyceae) "complex": perpetuating the paradox? Rev. Palaeobot. Palynol. 155 (1-2), 52-60. https://doi.org/10.1016/j.revpalbo.2008.12.017.

Röhl, U., Brinkhuis, H., Sluijs, A., Fuller, M., 2004. On the search for the Paleocene/ Eocene boundary in the Southern Ocean: exploring ODP Leg 189 holes 1171D and 1172D, Tasman Sea. In: Exon, N.F., Malone, M., Kennett, J.P. (Eds.), The Cenozoic Southern Ocean: Tectonics, Sedimentation, and Climate Change Between Australia and Antarctica. Geophysical Monograph Series American Geophysical Union, pp. 113-125.

van Roij, L., Sluijs, A., Laks, J.J., Reichart, G.-J., October 2016. Stable carbon isotope analyses of ng quantities of particulate organic carbon (pollen) with laser ablation nano combustion gas chromatography isotope ratio mass spectrometry. Rapid Commun. Mass Spectrom. 47-58, 2016. https://doi.org/10.1002/rcm.7769.

Schiøler, P., Brinkhuis, H., Roncaglia, L., Wilson, G.J., 1997. Dinoflagellate biostratigraphy and sequence stratigraphy of the type Maastrichtian (Upper Cretaceous), ENCI Quarry, The Netherlands. Mar. Micropaleontol. 31 (1-2), 65-95.

Schmidtko, S., Stramma, L., Visbeck, M., 2017. Decline in global oceanic oxygen content during the past five decades. Nature 542 (7641), 335-339. https://doi.org/10.1038/ nature21399.

Schmitz, B., Pujalte, V., 2007. Abrupt increase in seasonal extreme precipitation at the Paleocene-Eocene boundary. Geology 35 (3), 215-218. https://doi.org/10.1130/ G23261A.1.

Schoon, P.L., Heilmann-Clausen, C., Schultz, B.P., Sinninghe Damsté, J.S., Schouten, S., 2015. Warming and environmental changes in the eastern North Sea Basin during the Palaeocene-Eocene Thermal Maximum as revealed by biomarker lipids. Org. Geochem. 78, 79-88. https://doi.org/10.1016/j.orggeochem.2014.11.003.

Schouten, S., Hopmans, E.C., Schefu, E., Sinninghe Damsté, J.S., 2002. Distributional variations in marine crenarchaeotal membrane lipids: a new tool for reconstructing ancient sea water temperatures? Earth Planet. Sci. Lett. 204 (1-2), 265-274. https:// doi.org/10.1016/S0012-821X(02)00979-2.

Sherr, E.B., Sherr, B.F., 2007. Heterotrophic dinoflagellates: a significant component of microzooplankton biomass and major grazers of diatoms in the sea. Mar. Ecol. Ser. 352, 187.

Siringan, F.P., Azanza, R.V., Macalalad, N.J.H., Zamora, P.B., Maria, M.Y.Y.S., 2008 Temporal changes in the cyst densities of Pyrodinium bahamense var. compressum and other dinoflagellates in Manila Bay, Philippines. Harmful Algae 7 (4), 523-531.

Sluijs, A., Brinkhuis, H., 2009. A dynamic climate and ecosystem state during the Paleocene-Eocene Thermal Maximum - inferences from dinoflagellate cyst assemblages at the New Jersey Shelf. Biogeosciences 6 (8), 1755-1781. https://doi.org/10. 5194/bgd-6-5163-2009.

Sluijs, A., Dickens, G.R., 2012. Assessing offsets between the $\delta 13 \mathrm{C}$ of sedimentary components and the global exogenic carbon pool across early Paleogene carbon cycle perturbations. Glob. Biogeochem. Cycles 26 (4), 1-14. https://doi.org/10.1029/ 2011 GB004224.

Sluijs, A., Pross, J., Brinkhuis, H., 2005. From greenhouse to icehouse; organic-walled dinoflagellate cysts as paleoenvironmental indicators in the Paleogene. Earth-Sci. Rev. 68 (3-4), 281-315. https://doi.org/10.1016/j.earscirev.2004.06.001.

Sluijs, A., Schouten, S., Pagani, M., Woltering, M., Brinkhuis, H., Sinninghe Damsté, J.S., Dickens, G.R., Huber, M., Reichart, G.-J., Stein, R., Matthiessen, J., Lourens, L.J., Pedentchouk, N., Backman, J., Moran, K., the Expedition, S, 2006. Subtropical Arctic Ocean temperatures during the Palaeocene/Eocene thermal maximum. Nature 441 (7093), 610-613. https://doi.org/10.1038/nature04668.

Sluijs, A., Brinkhuis, H., Schouten, S., Bohaty, S.M., John, C.M., Zachos, J.C., Reichart, G.J., Sinninghe Damsté, J.S., Crouch, E.M., Dickens, G.R., 2007a. Environmental precursors to rapid light carbon injection at the Palaeocene/Eocene boundary. Nature 450 (7173), 1218-1221. https://doi.org/10.1038/nature06400.

Sluijs, A., Bowen, G.J., Brinkhuis, H., Lourens, L J., Thomas, E, 2007b. The PalaeoceneEocene Thermal Maximum super greenhouse: biotic and geochemical signatures, age models and mechanisms of global change. Geol. Soc. Spec. Publ. 323-349.

Sluijs, A., Röhl, U., Schouten, S., Brumsack, H.J., Sangiorgi, F., Sinninghe Damsté, J.S., Brinkhuis, H., 2008a. Article late Paleocene - Early Eocene paleoenvironments with special emphasis on the Paleocene-Eocene thermal maximum (Lomonosov Ridge, Integrated Ocean Drilling Program Expedition 302). Paleoceanography 23 (1). https://doi.org/10.1029/2007PA001495.

Sluijs, A., Brinkhuis, H., Crouch, E.M., John, C.M., Handley, L., Munsterman, D., Bohaty, S.M., Zachos, J.C., Reichart, G.J., Schouten, S., Pancost, R.D., Sinninghe Damsté, J.S. Welters, N.L.D., Lotter, A.F., Dickens, G.R., 2008b. Eustatic variations during the 
Paleocene-Eocene greenhouse world. Paleoceanography 23 (4), 1-18. https://doi. org/10.1029/2008PA001615.

Sluijs, A., Schouten, S., Donders, T.H., Schoon, P.L., Röhl, U., Reichart, G., Sangiorgi, F., Kim, J., Sinninghe Damsté, J.S., 2009. Warm and wet conditions in the Arctic region during Eocene Thermal Maximum 2. Nat. Geosci. 2 (November), 777-780. https:// doi.org/10.1038/NGEO668.

Sluijs, A., Bijl, P.K., Schouten, S., Röhl, U., Reichart, G.-J., Brinkhuis, H., 2011. Southern Ocean warming, sea level and hydrological change during the Paleocene-Eocene thermal maximum. Clim. Past 7 (1), 47-61. https://doi.org/10.5194/cp-7-47-2011.

Sluijs, A., Van Roij, L., Harrington, G.J., Schouten, S., Sessa, J.A., Levay, L.J., Reichart, G.J., Slomp, C.P., 2014. Warming, euxinia and sea level rise during the paleoceneeocene thermal maximum on the gulf coastal plain: implications for ocean oxygenation and nutrient cycling. Clim. Past 10 (4), 1421-1439. https://doi.org/10.5194/ cp-10-1421-2014.

Sluijs, A., van Roij, L., Frieling, J., Laks, J., Reichart, G.-J., 2018. Single-species dinoflagellate cyst carbon isotope ecology across the Paleocene-Eocene Thermal Maximum. Geology 46 (1), 79-82. https://doi.org/10.1130/G39598.1.

Stramma, L., Johnson, G.C., Sprintall, J., Mohrholz, V., 2008. Expanding oxygenminimum zones in the tropical oceans. Science 320 (5876), 655-658. https://doi. org/10.1126/science.1153847. (80-.).

Sunday, J.M., Bates, A.E., Dulvy, N.K., 2011. Global analysis of thermal tolerance and latitude in ectotherms. Proc. Biol. Sci. R. Soc. 278 (1713), 1823-1830. https://doi org $/ 10.1098 /$ rspb.2010.1295.

Tewksbury, J.J., Huey, R.B., Deutsch, C. a, 2008. Putting the heat on tropical animals. Science 320 (5881), 1296-1297. https://doi.org/10.1126/science.1159328.

Torricelli, S., Knezaurek, G., Biffi, U., 2006. Sequence biostratigraphy and paleoenvironmental reconstruction in the Early Eocene Figols Group of the Tremp-Graus Basin (South-Central Pyrenees, Spain). Palaeogeogr. Palaeoclimatol. Palaeoecol. 232 (1), 1-35. https://doi.org/10.1016/j.palaeo.2005.08.009.

Trommer, G., Siccha, M., van der Meer, M.T.J., Schouten, S., Sinninghe Damsté, J.S. Schulz, H., Hemleben, C., Kucera, M., 2009. Distribution of Crenarchaeota tetraether membrane lipids in surface sediments from the Red Sea. Org. Geochem. 40 (6), 724-731. https://doi.org/10.1016/j.orggeochem.2009.03.001.

Van Der Zwaan, G.J., Duijnstee, I.A.P., Den Dulk, M., Ernst, S.R., Jannink, N.T. Kouwenhoven, T.J., 1999. Benthic foraminifers: proxies or problems? A review of paleocological concepts. Earth Sci. Rev. 46 (1-4), 213-236.

van Hinsbergen, D.J.J., de Groot, L.V., van Schaik, S.J., Spakman, W., Bijl, P.K., Sluijs, A., Langereis, C.G., Brinkhuis, H., 2015. A paleolatitude calculator for paleoclimate studies. PLoS One 10 (6), e0126946. https://doi.org/10.1371/journal.pone. 0126946.

Versteegh, G.J.M., Blokker, P., Marshall, C., Pross, J., 2007. Macromolecular composition of the dinoflagellate cyst Thalassiphora pelagica (Oligocene, SW Germany). Org. Geochem. 38 (10), 1643-1656. https://doi.org/10.1016/j.orggeochem.2007.06.007.

Villanoy, C.L., Corrales, R.A., Jacinto, G.S., Cuaresma Jr., N.T., Crisostomo, R.P., 1996.
Towards the Development of a Cyst-Based Model for Pyrodinium Red Tides in Manila Bay, Philippines. Harmful toxic algal Bloom, Paris, pp. 189-192.

Villanoy, C.L., Azanza, R.V., Altemerano, A., Casil, A.L., 2006. Attempts to model the bloom dynamics of Pyrodinium, a tropical toxic dinoflagellate. Harmful Algae 5 (2), $156-183$.

Villarini, G., Vecchi, G.A., 2013. Projected increases in North Atlantic tropical cyclone intensity from CMIP5 models. J. Clim. 26 (10), 3231-3240. https://doi.org/10.1175/ JCLI-D-12-00441.1.

Wall, D., Dale, B., 1966. "Living fossils" in Western Atlantic plankton. Nature 211 (5053), 1025-1026.

Zachos, J.C., Rohl, U., Schellenberg, S.A., Sluijs, A., Hodell, D.A., Kelly, D.C., Thomas, E., Nicolo, M.J., Raffi, I., Lourens, L.J., McCarren, H.K., Kroon, D., 2005. Rapid acidification of the ocean during the Paleocene-Eocene Thermal Maximum. Science 308 (5728), 1611-1615. https://doi.org/10.1126/science.1109004.

Zachos, J.C., Schouten, S., Bohaty, S.M., Quattlebaum, T., Sluijs, A., Brinkhuis, H., Gibbs, S.J., Bralower, T.J., 2006. Extreme warming of mid-latitude coastal ocean during the Paleocene-Eocene Thermal Maximum: inferences from TEX86 and isotope data. Geology 34 (9), 737-740.

Zachos, J.C., Dickens, G.R., Zeebe, R.E., 2008. An early Cenozoic perspective on greenhouse warming and carbon-cycle dynamics. Nature 451 (7176), 279-283. https:// doi.org/10.1038/nature06588.

Zhou, X., Thomas, E., Winguth, A.M.E., Ridgwell, A., Scher, H., Hoogakker, B.A.A., Rickaby, R.E.M., Lu, Z., 2016. Expanded oxygen minimum zones during the late Paleocene-early Eocene: hints from multiproxy comparison and ocean modeling. Paleoceanography 1-15. https://doi.org/10.1002/2016PA003020.

Zonneveld, K.A.F., Versteegh, G.J.M., De Lange, G.J., 1997a. Preservation of dinoflagellate cysts in different oxygene regimes: a 10,000 year natural experiment. Mar. Micropaleontol. 29, 393-405.

Zonneveld, K.A.F., Versteegh, G.J.M., De Lange, G.J., 1997b. Preservation of organicwalled dinoflagellate cysts in different oxygen regimes: a 10,000 year natural experiment. Mar. Micropaleontol. 29 (3), 393-405.

Zonneveld, K.A.F., Susek, E., Fischer, G., 2010. Seasonal variability of the organic-walled dinoflagellate cyst production in the coastal upwelling region off Cape Blanc (Mauretania): a five year study. J. Phycol. 46 (1), 202-215. https://doi.org/10.1111/ j.1529-8817.2009.00799.x.

Zonneveld, K.A.F., Marret, F., Versteegh, G.J.M., Bogus, K., Bonnet, S., Bouimetarhan, I., Crouch, E., de Vernal, A., Elshanawany, R., Edwards, L., Esper, O., Forke, S., Grøsfjeld, K., Henry, M., Holzwarth, U., Kielt, J.-F., Kim, S.-Y., Ladouceur, S., Ledu, D., Chen, L., Limoges, A., Londeix, L., Lu, S.-H., Mahmoud, M.S., Marino, G., Matsouka, K., Matthiessen, J., Mildenhal, D.C., Mudie, P., Neil, H.L., Pospelova, V., Qi, Y., Radi, T., Richerol, T., Rochon, A., Sangiorgi, F., Solignac, S., Turon, J.-L., Verleye, T., Wang, Y., Wang, Z., Young, M., 2013. Atlas of modern dinoflagellate cyst distribution based on 2405 data points. Rev. Palaeobot. Palynol. 191, 1-197. https:// doi.org/10.1016/j.revpalbo.2012.08.003. 